\title{
Economics
}

The Open-Access, Open-Assessment E-Journal

Vol. 14, 2020-5 | February 11, 2020 | http://dx.doi.org/10.5018/economics-ejournal.ja.2020-5

\section{Exchange rate volatility in the eurozone}

\author{
Oscar Bajo-Rubio, Burcu Berke, and David McMillan
}

\begin{abstract}
The current economic crisis has witnessed a strong deceleration in the growth of international trade. This has been even greater in the cases of the European Unionand the eurozone, where the rates of export growth have even reached negative figures. In this paper, the authors examine to which extent exchange rate volatility might account for the drop in the rate of growth of exports in the eurozone since the start of the crisis. To that end, they estimate export functions, augmented to include several measures of exchange rate volatility, for the four largest economies of the eurozone, i.e., France, Germany, Italy and Spain, for the period 1994:1-2014:4. In the empirical application, the authors make use of two alternative measures for exchange rate volatility, i.e., (i) the Standard deviation and (ii) the conditional variance from the GARCH methodology, of the change in the logarithm of the exchange rate, for both nominal and real exchange rates, and in the latter case computed using as deflators both Export prices and unit labour costs. The empirical results show no clear-cut evidence on the impact of exchange rate volatility on the exports of the countries analysed, suggesting that financial markets were developed enough so that exchange rate volatility does not hinder the evolution of exports.
\end{abstract}

(Published in Special Issue Recent developments in international economics)

JEL F31 F41 F45

Keywords Exchange rate volatility; exports; eurozone

Authors

Oscar Bajo-Rubio, University of Castilla-La Mancha, Ciudad Real, Spain, oscar.bajo@uclm.es

Burcu Berke, Niğde Ömer Halisdemir University, Niğde, Turkey

David McMillan, University of Stirling, Stirling, Scotland, UK

Citation Oscar Bajo-Rubio, Burcu Berke, and David McMillan (2020). Exchange rate volatility in the eurozone. Economics: The Open-Access, Open-Assessment E-Journal, 14 (2020-5): 1-23. http://dx.doi.org/10.5018/economics-ejournal.ja.2020-5

Received October 7, 2019 Published as Economics Discussion Paper November 11, 2019

Revised January 13, 2020 Accepted February 3, 2020 Published February 11, 2020

(c) Author(s) 2020. Licensed under the Creative Commons License - Attribution 4.0 International (CC BY 4.0) 


\section{$1 \quad$ Introduction}

Last years have witnessed a strong deceleration in the growth of international trade. In Table 1, we show the annual average growth rates of exports for the world as a whole, the European Union (EU) and the eurozone, computed over the periods 1990-1999, 2000-2008, and 20092015. As can be seen, after the start of the crisis the rate of growth of world exports has experienced a huge fall, even greater in the cases of the EU and the eurozone, where the average growth rate over the period has even reached negative figures.

Certainly, the lower growth of international trade should be related to the fall in the GDP levels all over the world, associated with the crisis. However, unlike the trend present in the previous decades, when international trade grew much faster than world GDP, both variables are growing nowadays at similar rates. Two reasons have been suggested to account for this fact (Hoekman, 2015). On the one hand, the process of incorporation of both the Central and Eastern European countries and China to the global economy is now completed by the current decade. On the other hand, the expansion of the so-called global value chains (i.e., when different stages of the production process of a particular good or service are located across different countries) might also have come to a halt.

Following the breakdown of the Bretton Woods system in the early 1970s and the resulting move to freely floating exchange rates, the volatility of flexible exchange rates drew the attention of both academics and policy-makers. Since Mussa's (1979) classical contribution, the high variability of the exchange rates in the short run is a widely regarded empirical regularity. The short-run variability of the exchange rates was formalised in the well-known Dornbusch's (1976) overshooting model; and the role of the deviations of exchange rates from purchasing power parities in the medium run (the so-called "misalignment" problem) and its effects on trade were discussed in Williamson (1983). In fact, during the first years of the floating exchange rate regime, their volatility became a matter of concern as far as it could inhibit international trade; see, e.g., Group of Ten (1985). A comprehensive review of the performance of the floating exchange rate system over their first ten years, and its comparison with a less flexible regime, is provided in Obstfeld (1985).

How exchange rate volatility might affect negatively international trade? Since volatility is associated with the increased risk following an unexpected variation in the exchange rate, riskaverse exporters might reduce their output in response to a higher exchange rate volatility (McKenzie, 1999). From this point of view, the extent of exchange rate volatility might be a relevant factor in order to explain the decrease in the growth rates of international trade in last years.

Table 1: Annual average growth rates of exports

\begin{tabular}{lrrr}
\hline & World & \multicolumn{1}{c}{ EU } & Eurozone \\
\hline 1990-1999 & 6.52 & 6.23 & 6.42 \\
$2000-2008$ & 12.46 & 10.95 & 10.94 \\
2009-2015 & 1.40 & -0.51 & -0.88 \\
\hline Source: UNCTAD. & & &
\end{tabular}


However, there is no consensus among economists regarding how exchange rate volatility affects foreign trade volumes. According to the proponents of fixed exchange rates, floating rates are subject to excessive volatility, and deviations from equilibrium rate (i.e., exchange rate misalignments) may become permanent along time. Hence, exchange rate volatility reduces foreign trade volumes since most trade contracts are in the currency of either the importing or the exporting country, so affecting realized profits and hence the volume of foreign trade. Under these circumstances, either forward foreign exchange markets, which allow traders to eliminate such fluctuations in their profits, are not available, or traders cannot totally hedge foreign currency risk in their course of action (Dellas and Zilberfarb, 1993).

On the other hand, some authors also assert that exchange rate volatility might raise instead the volume of foreign trade, which could be justified on several grounds (Côté, 1994). For instance, even for risk-averse exporters, a higher risk does not necessarily involve a decline in risky activities. Also, the availability of hedging techniques allows exporters the avoidance of exchange rate risk at a small cost. In addition, exchange rate volatility may bring about some profitable trade opportunities; see Côté (1994) and the references therein.

Our aim in this paper will be to examine to which extent exchange rate volatility might account for the drop in the rate of growth of exports in the EU and, in particular, the eurozone since the start of the crisis. We try to contribute to the available literature on two main grounds: first, by providing some more recent evidence, including the crisis period, for the case of the eurozone; and, second, by making use of a broad battery of variables to proxy for exchange rate volatility. Specifically, we will analyse the four largest economies of the eurozone, namely, France, Germany, Italy and Spain, where these four countries accounted in 2015 for $76 \%$ of the GDP and 64\% of total exports of the eurozone. In line with most of the empirical literature on this issue, our approach will consist of estimating aggregate exports equations depending on foreign real income and external competitiveness, augmented to include the effect of exchange rate volatility. In order to check the robustness of our results, we will use several proxies for exchange rate volatility. In particular, exchange rate volatility will be measured in two alternative ways: (i) as the standard deviation of the change in the logarithm of the exchange rate, and (ii) as the conditional variance of the change in the logarithm of the exchange rate following the GARCH methodology. In addition, these two measures of volatility will be computed on both nominal and real exchange rates, in the latter case computed using as deflators both export prices and unit labour costs. Overall, this gives us up to six different measures of volatility for each country analysed.

Some evidence on the evolution of the exchange rate between the euro and the US dollar is presented in Figure 1. The figure shows the wide fluctuations of the exchange rate of the euro since its inception in 1999, which might have affected the evolution of the exports of the eurozone via an increased risk.

The paper is organized as follows. In Section 2, we present a brief overview of the main findings from the literature on exchange rate volatility and trade flows, from both a theoretical and empirical point of view. In Section 3 we discuss the methods and data and then, the results of our empirical exercise are reported in Section 4. Finally, the main conclusions are summarised in Section 5. 
Figure 1: Nominal exchange rate euro/US dollar, 1999-2015

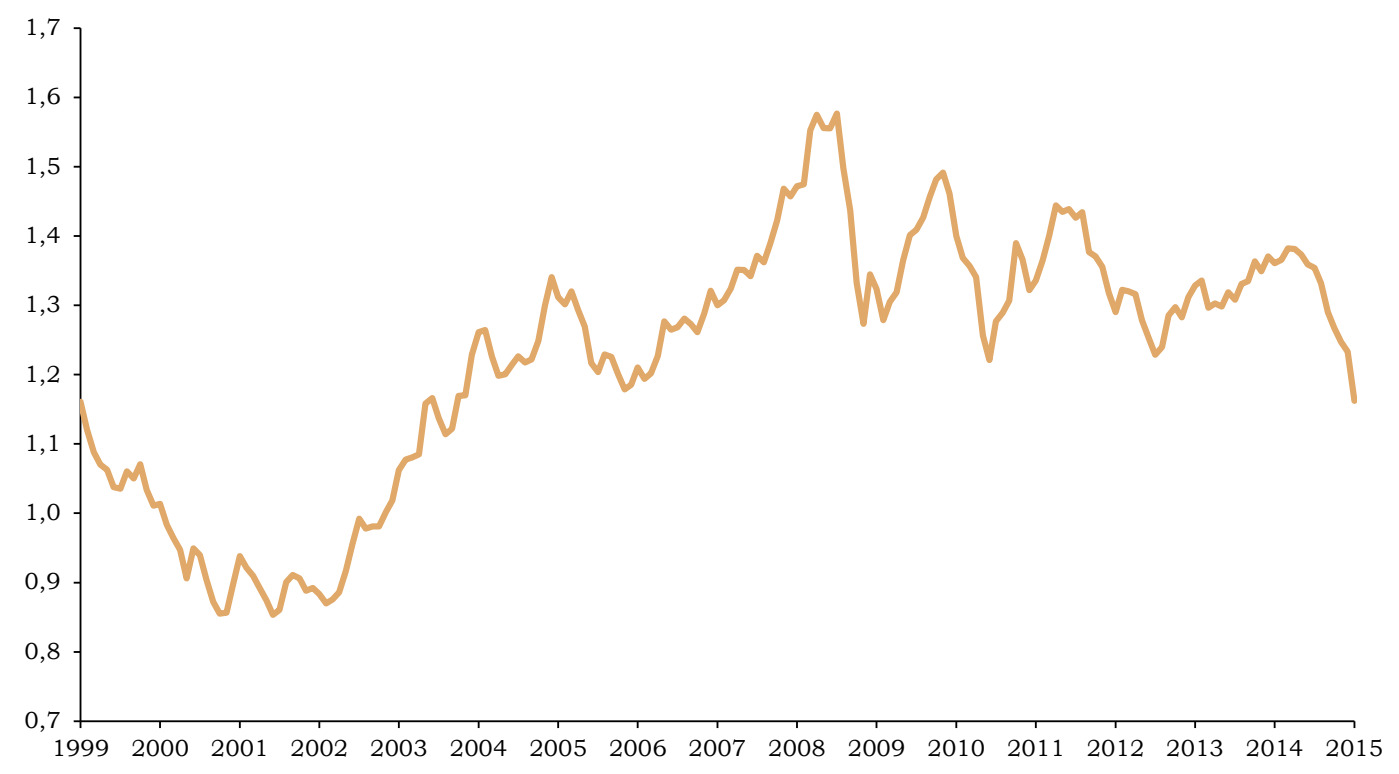

Source: Eurostat.

\section{Literature review}

In this section, we will review the main results of the literature on exchange rate volatility and trade flows; broader surveys can be found in Côté (1994), McKenzie (1999) or BahmaniOskooee and Hegerty (2007).

We start by reviewing the possible reasons that might explain, from a theoretical point of view, the relationship between exchange rate volatility and exports. The first theoretical analyses, appeared at the time of the launching of the system of floating exchange rates at the start of the 1970s, claimed that a higher volatility translates into a reduction in the volume of foreign trade, on increasing the uncertainty on the exporting firms' revenue (Ethier, 1973). In a similar vein, Hooper and Kohlhagen (1978) found that, when the exchange rate cannot be fully predicted, risk-averse firms will reduce the volume of trade. The effect on the price of traded goods, though, could go in any direction, depending on who bears the risk, i.e., the exporter or the importer.

However, the subsequent theoretical literature has emphasised that exchange rate volatility can have both positive and negative effects on foreign trade levels. For instance, De Grauwe (1988) argued that a positive relationship between exchange rate volatility and the volume of trade may appear when the income effect dominates over the substitution effect following an increase in risk. In other words, when risk increases, very risk-averse firms will export more to avoid the possibility of a large fall in their revenues, unlike less risk-averse firms, which will export less since exporting now becomes less attractive due to higher risk; see De Grauwe (1988: 67). 
Further contributions have emphasised different reasons that can lead to a positive relationship between exchange rate volatility and the volume of trade. For instance, Franke (1991) showed that, in a model where firms have entry and exit costs, a firm with a comparative disadvantage will find that its expected cash flows from exporting grow faster with exchange rate volatility than the expected entry and exit costs. Similar results were obtained by Sercu (1992) in a model with tariffs and transport costs instead of entry and exit costs. Also, Dellas and Zilberfarb (1993) related the positive effect of exchange rate volatility on foreign trade to the avoidance of risk so that, when the latter increases, the effect on foreign trade becomes positive. In turn, using a different approach, Broll and Eckwert (1999) found that, since industries can easily distribute their products across different markets, and when the parameter of risk avoidance risk is not excessively high, a positive correlation may be expected between the export volumes and exchange rate volatility. Finally, an interesting contribution is Barkoulas et al. (2002), who differentiate three sources of exchange rate uncertainty, i.e., general microstructure aspects of the foreign exchange market, exchange rate fundamentals, and future policy innovations; and analyse their effects on both the volume and variability of trade flows. Their results show that the first source of uncertainty affects negatively the volume and variability of trade flows; unlike the other two, which have an ambiguous effect on trade volume but positive and negative effects, respectively, on their variability.

There are many available empirical studies on the relationship between exchange rate volatility and foreign trade. The results, however, are at best mixed, depending on the sample period and the countries analysed, as well as on the choice of proxies for exchange rate volatility. The first studies, conducted for developed countries over the period following the adoption of floating exchange rates in the early 1070s, concluded that a greater variability of exchange rates, both nominal and real, hinders the volume of foreign trade; see, e.g., Kenen and Rodrik (1986), Thursby and Thursby (1987), or De Grauwe (1988). However, De Grauwe (1988) pointed at other factors, such as the fall in output growth and the slowdown of the trade integration processes, as having a stronger influence than volatility when explaining the lower growth of international trade since 1973. Further results along these lines were found by Koray and Lastrapes (1989), Perée and Steinherr (1989), Chowdhury (1993) or Arize (1997). Pozo (1992) showed how a higher real exchange rate volatility affected negatively the British exports to the US over the period 1900-1940. In turn, the negative effect of real exchange rate volatility on the trade flows of developing countries between 1973 and 1996 was documented in Doroodian (1999) and Arize et al. (2000).

These conclusions were challenged by subsequent research. An early contribution was Gotur (1985), who questioned previous results on methodological grounds, and concluded that, while significant adverse effects of exchange rate volatility on trade volumes can be detected in some cases, the results as a whole tend to be insignificant or unstable. Later on, McKenzie and Brooks (1997) obtained a positive effect of exchange rate volatility on the bilateral trade flows between Germany and the US for the period 1973-1992. McKenzie (1998) found that, while exchange rate volatility affected Australian aggregate exports positively, it affected imports negatively, at the same time that the effect differed across particular industries. In a long-run perspective, Aristotelous (2001) found no effect of exchange rate volatility on British exports to the US over the period 1889-1999. By estimating a gravity equation for trade, using data for 87 countries (both advanced and developing) over the period 1970-1997, Tenreyro (2007) 
concluded that nominal exchange rate volatility had no significant impact on trade volumes. According to the author, these results suggest that the availability of financial instruments allow firms to hedge from the adverse effects of exchange rate risk. Finally, in a recent study on four commodity exporting countries for the period 1990-2013, Mordecki and Miranda (2019) found that conditional real exchange rate volatility was not significant for Brazil, Chile and New Zealand, unlike the case of Uruguay, where it affected negatively exports both in the short and the long run.

However, the most recent research stresses that the negative effect of exchange rate volatility on trade flows should be more important for developing countries; see, e.g., Grier and Smallwood (2007) and Héricourt and Poncet (2015). The main reason behind is the lower development of financial markets in those countries, making difficult for exporting firms to hedge against exchange rate fluctuations, which is aggravated by the existence of sunk costs related to entering foreign markets (such as collecting information, creating distribution channels, adapting products to local tastes, and the like). The presence of these costs means that financially vulnerable firms in developing countries are reluctant to engage in export activities when exchange rate volatility is high. Other sources that inhibit forward cover might occur if real rather than nominal rates matter to firms, or if exchange rate fluctuations are low-frequency.

To conclude, we will mention some papers that apply meta-analysis techniques to the available empirical literature on the effects of exchange rate volatility on trade; see, e.g., Corić and Pugh (2010) or Bouoiyour and Selmi (2016). In particular, in the latter paper 59 studies published between 1984 and 2014 are examined, with 29 of them supporting a negative effect of exchange rate uncertainty on trade, 6 finding a positive effect, 6 a non-significant effect, and 18 an ambiguous effect. These dissimilar findings are attributed by the authors to several factors, such as the heterogeneity of the country analysed (advanced or developing), the measurement of volatility utilised, or the nature of the exports considered (e.g., total or sectoral).

\section{Methods and data}

In order to analyse the influence of exchange rate volatility on the evolution of exports, our starting point will be the standard demand for exports equation. Specifically, we will make use of the imperfect substitutes model, which assumes that exports are not perfect substitutes for domestic goods. This assumption can be justified given the price differences existing across manufactured goods (i.e., the main component of international trade); also, the important role achieved by intra-industry trade provides additional support for the hypothesis. As in conventional demand theory, the importing agent behaves as a consumer that maximises utility subject to a budget constraint. Thus, the resulting demand function characterises the quantity of exports demanded by the rest of the world as a positive function of the level of foreign income and of the price of the goods produced in the rest of the world that substitute for exports, and a negative function of the price of exports. Assuming further that the price elasticity of the supply of exports is infinite allows to estimate the demand function by single-equation methods. Goldstein and Khan (1985) provide a comprehensive analysis of the theoretical and methodological problems associated with the estimation of aggregate foreign trade functions. 
In line with most of the empirical literature reviewed in the previous section, our approach will consist of estimating aggregate exports equations, as specified by the imperfect substitutes model, including as an additional variable exchange rate volatility. In other words, we will try to assess whether the inclusion of volatility (i.e., our variable of interest) changes the results from the estimation of the standard model for exports. Specifically, we will estimate an equation with aggregate exports depending on foreign real income and external competitiveness, augmented to include the effect of exchange rate volatility:

$$
X=f\left(Y^{*}, q \text {, volatility }\right)
$$

where $X, Y^{*}$ and $q$ denote, respectively, the volume of exports, the level of foreign real income and a measure of external competitiveness, defined as the price of domestic goods relative to foreign goods. Hence, in line with the available literature, our approach consists of testing whether the addition of the exchange rate volatility can add some explanatory power to an otherwise standard export equation.

In the empirical application, we have taken as proxies of foreign real income and external competitiveness, respectively, the GDP of the OECD and the real effective exchange rate (REER). The data utilised in the estimations and their sources are:

- Exports in goods: US dollars, at current prices, converted to 2005 prices using the GDP deflator. Source: OECD.Stat.

- GDP of the OECD: million US dollars, at 2005 prices. Source: OECD.Stat.

- Nominal effective exchange rates versus 37 industrialized countries: indices, 2005=100. Source: Eurostat.

- Real effective exchange rates versus 37 industrialized countries: indices, 2005=100. Two alternative definitions of the REER have been used, computed using as deflators export prices and unit labour costs (ULCs). Source: Eurostat.

The data are quarterly and seasonally adjusted, and the time period is 1994:1-2014:4. As usual, an increase in the REER means an appreciation of the real exchange rate, and hence a loss of competitiveness; and, conversely, a decrease in the REER means a depreciation of the real exchange rate, and hence a gain of competitiveness.

An important point here is how to measure exchange rate volatility. Many measures have been proposed and utilised in the literature, ranging from some measure of variance to the residuals of ARIMA models or, more recently, the conditional variance from ARCH models; see McKenzie (1999) or Bahmani-Oskooee and Hegerty (2007) for a review. In this paper, we will make use of two alternative measures:

(i) first, a simpler and more traditional one, namely, as the standard deviation of the change in the logarithm of the exchange rate; and

(ii) second, as the conditional variance of the change in the logarithm of the exchange rate following the generalized autoregressive conditional heteroscedasticity (GARCH) methodology (Engle, 1982; Bollerslev, 1986). 
More specifically, our second proxy of volatility has been obtained from an EGARCH(1,1) model, where EGARCH denotes “exponential GARCH”. The EGARCH model (Nelson, 1991) has been widely used in the modelling of asset prices, and is based on the assumption that volatility is asymmetrical, i.e., responds differently when facing either a rise or a fall in the price of an asset, where a positive shock has less effect on the conditional variance compared to a negative shock.

Finally, these two measures of volatility will be computed on both nominal and real exchange rates. Notice that, on the other hand, when examining long-term trends traders bear in mind real, rather than nominal, exchange rates. However, some authors have stressed the relationship of risk with nominal exchange rates, which might have an effect in turn on trade flows. Accordingly, we will assess in our empirical exercise the role of both nominal and real exchange rate volatility on the evolution of trade flows.

\section{Empirical results}

Equation (1) will be estimated for the four largest economies of the eurozone, namely, France, Germany, Italy and Spain. In Table 2 we present some descriptive statistics for the variables included in that equation. In the table, $L X, L Y^{*}, L R E E R \_E X P$ and LREER_ULC denote the logs of exports, OECD's GDP, and the REER computed using export prices and ULCs, respectively. In turn, VNEER, VREER_EXP and VREER_ULC are the volatilities of nominal effective exchange rates and the two REERs, respectively, with 1 and 2 denoting the two alternative measures of volatility, namely, the standard deviation and the conditional variance from an EGARCH model.

The next step is testing for the order of integration of the variables by means of the modified version of the Phillips-Perron tests proposed by Ng and Perron (2001), intended to improve those tests with regard to both size distortions and power. The results are shown in Table 3 and, as can be seen, the variables exports, foreign income and REER (computed using both export prices and ULCs) are integrated of order one. Regarding the different volatility measures, they are stationary in all cases with the exceptions of VNEER2 for Germany, and VNEER1, VNEER2, $V R E E R \_E X P 2$ and VREER_ULC2 for Italy, where the Ng-Perron test does not reject the null of $\mathrm{I}(1)$.

However, since conventional unit root tests are biased toward accepting the null of a unit root when the series is stationary with a structural break (Perron, 1989), we have performed a modified augmented Dickey-Fuller test allowing for a breakpoint on the above variables. Two alternative models have been considered, namely, the innovational outlier model (IOM), which assumes that the break occurs gradually, and the additive outlier model (AOM), which assumes that the break occurs immediately. The test selects the breakpoints by minimising the $t$-statistic of the autoregressive term in the Dickey-Fuller equation. The results, shown in Table 4, allow us to reject in all cases the null hypothesis of a unit root. 


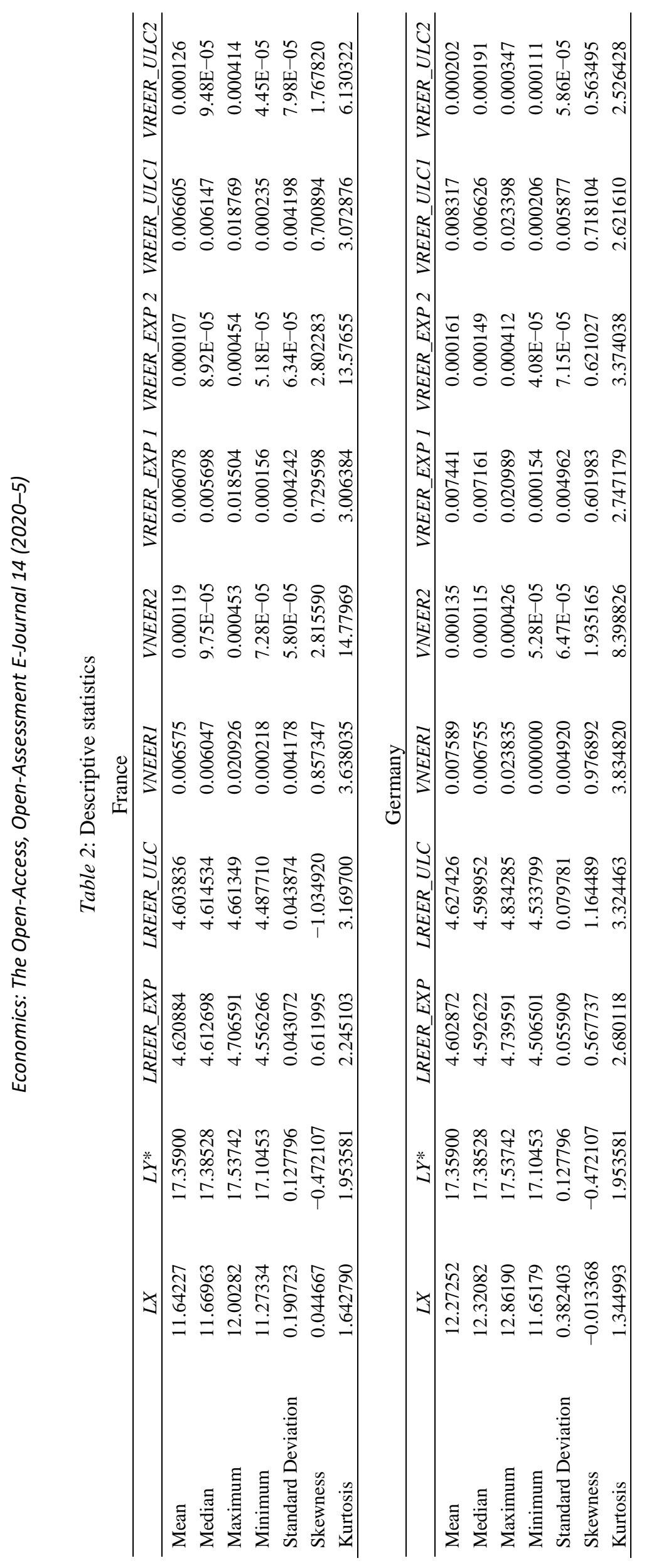

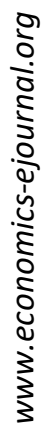




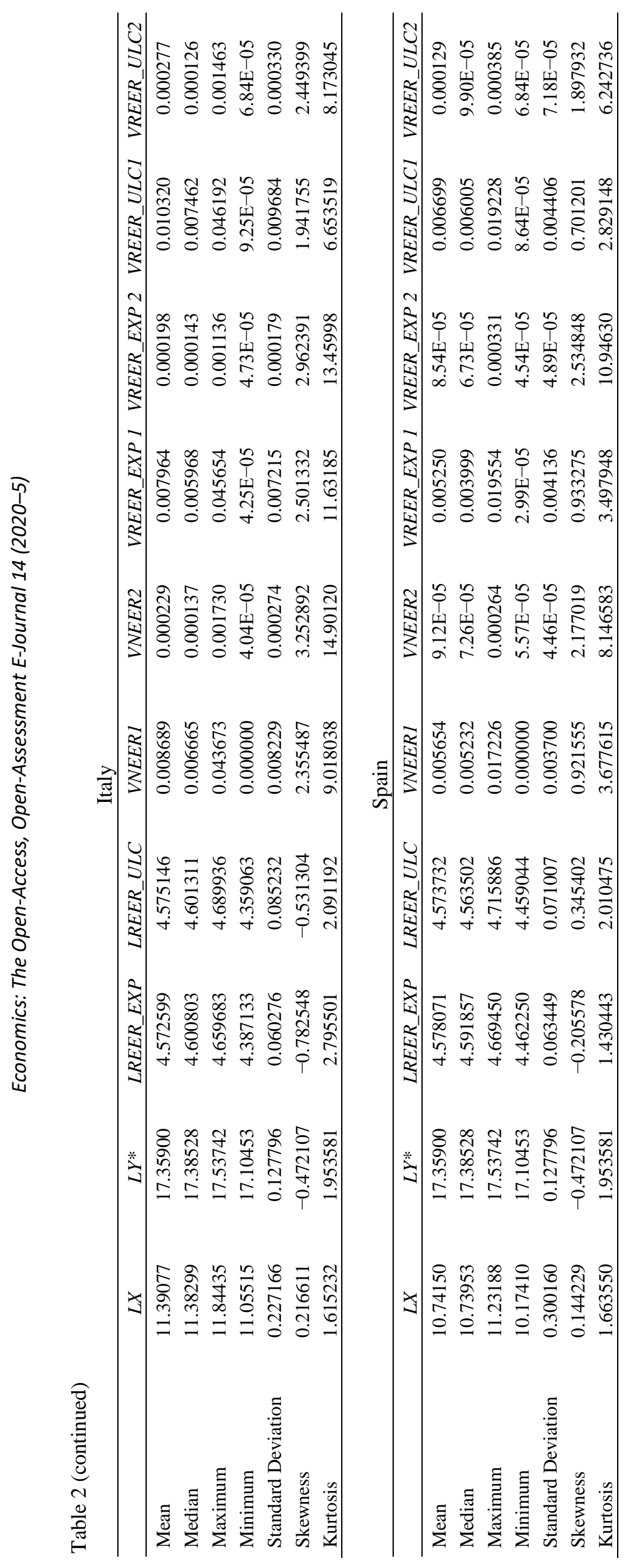


Economics: The Open-Access, Open-Assessment E-Journal 14 (2020-5)

Table 3: Unit root tests

\begin{tabular}{|c|c|c|c|c|c|c|c|c|}
\hline & \multicolumn{4}{|c|}{ France } & \multicolumn{4}{|c|}{ Germany } \\
\hline & $M Z_{\alpha}$ & $M Z_{t}$ & $M S B$ & $M P_{T}$ & $M Z_{\alpha}$ & $M Z_{t}$ & $M S B$ & $M P_{T}$ \\
\hline$L X$ & -0.887 & -0.465 & 0.524 & 17.02 & 0.522 & 0.490 & 0.938 & 56.44 \\
\hline$L Y^{*}$ & 0.083 & 0.827 & 0.936 & 60.58 & 0.083 & 0.827 & 0.936 & 60.58 \\
\hline LREER_EXP & -0.918 & -0.442 & 0.481 & 15.32 & -1.400 & -0.591 & 0.423 & 12.22 \\
\hline LREER_ULC & -5.072 & -1.570 & 0.310 & 4.888 & -1.644 & -0.807 & 0.491 & 13.24 \\
\hline VNEER1 & $-40.37^{\mathrm{a}}$ & $-4.477^{\mathrm{a}}$ & $0.111^{\mathrm{a}}$ & $0.651^{\mathrm{a}}$ & $-39.06^{\mathrm{a}}$ & $-4.418^{\mathrm{a}}$ & $0.113^{\mathrm{a}}$ & $2.337^{\mathrm{a}}$ \\
\hline$V R E E R \_E X P 1$ & $-29.49^{\mathrm{a}}$ & $-3.840^{\mathrm{a}}$ & $0.130^{\mathrm{a}}$ & $0.831^{\mathrm{a}}$ & $-34.96^{\mathrm{a}}$ & $-4.155^{\mathrm{a}}$ & $0.119^{\mathrm{a}}$ & $0.778^{\mathrm{a}}$ \\
\hline VREER_ULC1 & $-35.21^{\mathrm{a}}$ & $-4.194^{\mathrm{a}}$ & $0.119^{\mathrm{a}}$ & $0.700^{\mathrm{a}}$ & $-34.53^{\mathrm{a}}$ & $-4.097^{\mathrm{a}}$ & $0.119^{\mathrm{a}}$ & $0.880^{\mathrm{a}}$ \\
\hline VNEER2 & $-38.70^{\mathrm{a}}$ & $-4.382^{\mathrm{a}}$ & $0.113^{\mathrm{a}}$ & $0.680^{\mathrm{a}}$ & 0.054 & 0.054 & 1.008 & 57.42 \\
\hline VREER_EXP2 & $-37.71^{\mathrm{a}}$ & $-4.333^{\mathrm{a}}$ & $0.115^{\mathrm{a}}$ & $0.674^{\mathrm{a}}$ & $-10.32^{\mathrm{b}}$ & $-2.193^{\mathrm{b}}$ & $0.213^{\mathrm{b}}$ & $2.683^{\mathrm{b}}$ \\
\hline VREER_ULC2 & $-31.42^{\mathrm{a}}$ & $-3.941^{\mathrm{a}}$ & $0.125^{\mathrm{a}}$ & $0.848^{\mathrm{a}}$ & $-10.30^{\mathrm{b}}$ & $-2.165^{b}$ & $0.210^{\mathrm{b}}$ & $2.785^{\mathrm{b}}$ \\
\hline & \multicolumn{4}{|c|}{ Italy } & \multicolumn{4}{|c|}{ Spain } \\
\hline & $M Z_{\alpha}$ & $M Z_{t}$ & $M S B$ & $M P_{T}$ & $M Z_{\alpha}$ & $M Z_{t}$ & $M S B$ & $M P_{T}$ \\
\hline$L X$ & -1.630 & -0.714 & 0.438 & 12.00 & 0.067 & 0.041 & 0.614 & 25.75 \\
\hline$L Y^{*}$ & 0.083 & 0.827 & 0.936 & 60.58 & 0.083 & 0.827 & 0.936 & 60.58 \\
\hline LREE & -0.693 & -0.401 & 0.579 & 20.13 & 0.325 & 0.374 & 1.149 & 77.58 \\
\hline LREER_ULC & -3.021 & -1.072 & 0.355 & 7.824 & -2.037 & -0.997 & 0.489 & 11.90 \\
\hline VNEER1 & -3.147 & -1.147 & 0.365 & 7.644 & $-24.12^{\mathrm{a}}$ & $-3.437^{\mathrm{a}}$ & $0.143^{\mathrm{a}}$ & $1.136^{\mathrm{a}}$ \\
\hline$V R E E R \_E X P 1$ & $-20.16^{\mathrm{b}}$ & $-3.170^{\mathrm{b}}$ & $0.157^{\mathrm{b}}$ & $4.551^{\mathrm{b}}$ & $-37.04^{\mathrm{a}}$ & $-4.297^{\mathrm{a}}$ & $0.116^{\mathrm{a}}$ & $2.498^{\mathrm{a}}$ \\
\hline VREER_ULC1 & $-34.00^{\mathrm{a}}$ & $-4.116^{\mathrm{a}}$ & $0.121^{\mathrm{a}}$ & $2.721^{\mathrm{a}}$ & $-37.63^{\mathrm{a}}$ & $-4.327^{\mathrm{a}}$ & $0.115^{\mathrm{a}}$ & $0.681^{\mathrm{a}}$ \\
\hline VNEER $\overline{2}$ & -1.419 & -0.715 & 0.504 & 14.37 & $-37.97^{\mathrm{a}}$ & $-4.350^{\mathrm{a}}$ & $0.115^{\mathrm{a}}$ & $0.666^{\mathrm{a}}$ \\
\hline VREER_EXP2 & -3.993 & -1.334 & 0.334 & 6.220 & $-40.10^{\mathrm{a}}$ & $-4.468^{\mathrm{a}}$ & $0.111^{\mathrm{a}}$ & $0.640^{\mathrm{a}}$ \\
\hline VREER_ULC2 & 0.409 & 0.561 & 1.370 & 109.52 & $-34.33^{\mathrm{a}}$ & $-4.125^{\mathrm{a}}$ & $0.120^{\mathrm{a}}$ & $0.769^{\mathrm{a}}$ \\
\hline
\end{tabular}

Notes:

(i) ${ }^{\mathrm{a}},{ }^{\mathrm{b}}$ and ${ }^{\mathrm{c}}$ denote significance at the $1 \%, 5 \%$ and $10 \%$ levels, respectively. The critical values are taken from $\mathrm{Ng}$ and Perron (2001, Table I).

(ii) The tests for VNEER1 for Germany, VREER_EXP1 and VREER_ULC1 for Italy, and VREER_EXP1 for Spain, include a linear trend.

Table 4: Unit root tests with breakpoints

\begin{tabular}{lcccc}
\hline & \multicolumn{2}{c}{ IOM } & \multicolumn{2}{c}{ AOM } \\
\hline & $t$-statistic & Break date & $t$-statistic & Break date \\
\hline Germany & & & & \\
VNEER2 & $-7.319^{\mathrm{a}}$ & $2001: 1$ & $-6.619^{\mathrm{a}}$ & $2002: 3$ \\
$\quad$ Italy & & & & \\
VNEER1 & $-5.822^{\mathrm{a}}$ & $1998: 1$ & $-6.236^{\mathrm{a}}$ & $1997: 3$ \\
VNEER2 & $-4.514^{\mathrm{b}}$ & $1997: 4$ & $-11.80^{\mathrm{a}}$ & $2009: 3$ \\
VREER_EXP2 & $-5.444^{\mathrm{a}}$ & $1997: 4$ & $-7.888^{\mathrm{a}}$ & $2009: 1$ \\
VREER_ULC2 & $-5.483^{\mathrm{a}}$ & $2014: 3$ & $-5.167^{\mathrm{a}}$ & $2012: 1$ \\
\hline
\end{tabular}

Note: ${ }^{\mathrm{a}}$ and ${ }^{\mathrm{b}}$ denote significance at the $1 \%$ and $5 \%$ levels, respectively. The critical values are taken from Vogelsang (1993). 
Next, we have tested for the presence of cointegration among the I(1) variables, i.e., $L X$, $L Y^{*}$ and LREER, using the test of Johansen (1991). According to the results in Table 5, no evidence of cointegration was found in any case. ${ }^{1}$

Therefore, we proceed to estimate equations of the form:

$$
\Delta L X_{t}=\text { constant }+\alpha \Delta L Y_{t}^{*}+\beta \Delta L R E E R_{t}+\gamma(\text { volatility })_{t-1}+v_{t}
$$

where LREER includes our two definitions (i.e., using export prices and ULCs) and exchange rate volatility can be nominal or real, and is measured using either the standard deviation or the conditional variance from an EGARCH model; $\Delta$ is the first difference operator; and $v_{t}$ is an error term. The results of the estimations appear in Tables 6, 7, 8 and 9, for France, Germany,

Table 5: Cointegration tests

Variables: $L X, L Y^{*}, L R E E R \_E X P$

\begin{tabular}{|c|c|c|c|c|c|c|}
\hline & $\begin{array}{c}\text { No. of } \\
\text { cointegrating } \\
\text { relations }\end{array}$ & $\begin{array}{c}0.01 \text { critical } \\
\text { values }\end{array}$ & France & Germany & Italy & Spain \\
\hline & None & 35.458 & 24.906 & 19.394 & 25.202 & 23.149 \\
\hline \multirow[t]{3}{*}{ Trace } & At most 1 & 19.937 & 8.344 & 8.312 & 12.005 & 9.682 \\
\hline & At most 2 & 6.635 & 2.967 & 2.850 & 5.399 & 2.875 \\
\hline & None & 25.861 & 16.562 & 11.083 & 13.197 & 13.467 \\
\hline \multirow[t]{5}{*}{$\lambda \max$} & At most 1 & 18.520 & 5.378 & 5.461 & 6.606 & 6.807 \\
\hline & At most 2 & 6.635 & 2.967 & 2.850 & 5.399 & 2.875 \\
\hline & \multicolumn{6}{|c|}{ Variables: $L X, L Y^{*}, L R E E R \_U L C$} \\
\hline & $\begin{array}{c}\text { No. of } \\
\text { cointegrating } \\
\text { relations }\end{array}$ & $\begin{array}{c}0.01 \text { critical } \\
\text { values }\end{array}$ & France & Germany & Italy & Spain \\
\hline & None & 35.458 & 29.883 & 22.105 & 32.239 & 15.604 \\
\hline \multirow[t]{3}{*}{ Trace } & At most 1 & 19.937 & 9.823 & 4.750 & 10.178 & 6.817 \\
\hline & At most 2 & 6.635 & 2.504 & 0.326 & 4.716 & 1.504 \\
\hline & None & 25.861 & 20.060 & 17.354 & 22.061 & 8.787 \\
\hline \multirow[t]{2}{*}{$\lambda \max$} & At most 1 & 18.520 & 7.319 & 4.424 & 5.462 & 5.313 \\
\hline & At most 2 & 6.635 & 2.504 & 0.326 & 4.716 & 1.504 \\
\hline
\end{tabular}

Notes:

(i) Trace and $\lambda$ max denote, respectively, the trace and maximum eigenvalue likelihood ratio statistics for the number of cointegrating vectors.

(ii) None of the test statistics is significant at the $1 \%$ level. The critical values are taken from MacKinnon et al. (1999).

\footnotetext{
1 We have also performed the test of Gregory and Hansen (1996) for cointegration with a break, and the results do not show any meaningful evidence of cointegration even allowing for a break; the results, not shown here for space reasons, are available from the authors upon request.
} 
Italy and Spain, respectively. The estimation method is OLS with the Newey-West correction of standard errors for heteroscedasticity and autocorrelation (Newey and West, 1987). In all tables, the REER is measured as LREER_EXP in Equations 1 to 4, and as LREER_ULC in Equations 5 to 8. Regarding volatility, Equations 1, 2, 5 and 6 use the volatility of the nominal exchange rate, and Equations 3, 4, 7 and 8 use the volatility of the real exchange rate; in both cases measured using alternatively the standard deviation (Equations 1, 3, 5 and 7) or the conditional variance from an EGARCH model (Equations 2, 4, 6 and 8). ${ }^{2}$

On the other hand, equations denoted with $b$ in the tables include a dummy variable dum that splits the sample before and after the start of the crisis, so that dum $=1$ from 2008:4 on. Finally, for the sake of completeness, in equations denoted with $c$ we have split the sample alternatively before and after the start of the Economic and Monetary Union (EMU), of which the four countries analysed were founding members, and the resulting adoption of the euro, so that now dum = 1 from 1999:1 on. Accordingly, the estimated equations are in these cases:

$$
\begin{aligned}
\Delta L X_{t}= & {\left[\text { constant }+\alpha \Delta L Y_{t}^{*}+\beta \Delta L R E E R_{t}+\gamma\left({\text { volatility } \left.)_{t-1}\right]}^{*}(1-d u m)+\right.\right.} \\
& +\left[\text { constant }+\alpha^{\prime} \Delta L Y_{t}^{*}+\beta^{\prime} \Delta L R E E R_{t}+\gamma^{\prime}\left(\text { volatility }_{t-1}\right] * d u m+v_{t}^{\prime}\right.
\end{aligned}
$$

Starting with the estimations of Equation (2), i.e., equations denoted with $a$ in Tables 6 to 9, we can see, first, that both foreign output and the REER always appear with a positive and significant coefficient. In the latter case, this might indicate the existence of a J-curve effect in the short run, since we are estimating our equations in first differences. With regard to volatility, nominal volatility seems to have a negative and significant effect on German exports, but real volatility is not significant in most cases. However, the coefficient on the volatility variable is significant just twice for France (for VREER_EXP2 and VNEER2, with a positive sign and at the $10 \%$ level) and Spain (both for VNEER1, with a negative sign and the first time at the $10 \%$ level), and never for Italy.

Next, we have split the sample before and after the start of the crisis, by introducing a dummy variable for the second (i.e., crisis) period. When estimating Equation (2'), i.e., equations denoted with $b$ in Tables 6 to 9, the effect of foreign output on exports is always stronger in the crisis period; and the coefficient on the dummy (with a negative sign) is generally significant for Germany and about half of the times for Italy, but is generally nonsignificant for France and Spain. Although the results for the first subperiod are roughly the same than those for the whole period, some differences appear for the second subperiod. The effect of volatility is significant for Germany only when computed from the conditional variance from an EGARCH model, with a negative and positive sign for nominal (in this case, only at a $10 \%$ level) and real volatility, respectively. Finally, the results are similar again for the other three countries, with both nominal and real volatility measured from the EGARCH model (in the case of Italy, only for the REER computed using export prices) having a positive and significant effect on exports.

\footnotetext{
2 Some formal tests have been also performed, revealing there is no residual autocorrelation or heteroscedasticity; again, the results are not shown for space reasons, but they available from the authors upon request.
} 
Economics: The Open-Access, Open-Assessment E-Journal 14 (2020-5)

Table 6: Exports and exchange rate volatility: France

\begin{tabular}{|c|c|c|c|c|c|c|c|c|}
\hline Equation & constant & $\Delta L Y^{*}$ & $\triangle L R E E R$ & volatility & constant & $\Delta L Y^{*}$ & $\triangle L R E E R$ & volatility \\
\hline $1 a$ & $\begin{array}{l}-0.013^{\mathrm{C}} \\
(-1.90)\end{array}$ & $\begin{array}{l}4.631^{\mathrm{a}} \\
(6.22)\end{array}$ & $\begin{array}{c}2.646^{\mathrm{a}} \\
(10.04)\end{array}$ & $\begin{array}{l}-0.038 \\
(-0.05)\end{array}$ & - & - & - & - \\
\hline $1 b$ & $\begin{array}{l}-0.002 \\
(-0.16)\end{array}$ & $\begin{array}{l}2.485^{b} \\
(2.04)\end{array}$ & $\begin{array}{l}2.625^{a} \\
(9.03)\end{array}$ & $\begin{array}{l}0.057 \\
(0.06)\end{array}$ & $\begin{array}{l}-0.006 \\
(-0.42)\end{array}$ & $\begin{array}{c}5.776^{\mathrm{a}} \\
(12.87)\end{array}$ & $\begin{array}{l}2.421^{\mathrm{a}} \\
(5.63)\end{array}$ & $\begin{array}{l}-1.040 \\
(-0.76)\end{array}$ \\
\hline $1 c$ & $\begin{array}{l}0.000 \\
(0.00)\end{array}$ & $\begin{array}{l}-0.686 \\
(-0.20)\end{array}$ & $\begin{array}{l}2.216^{\mathrm{a}} \\
(5.12)\end{array}$ & $\begin{array}{l}2.795^{b} \\
(2.25)\end{array}$ & $\begin{array}{l}-0.009 \\
(-0.32)\end{array}$ & $\begin{array}{l}4.993^{\mathrm{a}} \\
(8.72)\end{array}$ & $\begin{array}{l}2.692^{\mathrm{a}} \\
(8.83)\end{array}$ & $\begin{array}{l}-0.857 \\
(-1.06)\end{array}$ \\
\hline $2 a$ & $\begin{array}{c}-0.021^{\mathrm{b}} \\
(-2.91)\end{array}$ & $\begin{array}{l}4.641^{\mathrm{a}} \\
(6.24)\end{array}$ & $\begin{array}{c}2.670^{\mathrm{a}} \\
(11.10)\end{array}$ & $\begin{array}{l}65.702 \\
(1.50)\end{array}$ & - & - & - & - \\
\hline $2 b$ & $\begin{array}{l}-0.003 \\
(-0.21)\end{array}$ & $\begin{array}{l}2.456^{\mathrm{C}} \\
(1.94)\end{array}$ & $\begin{array}{l}2.638^{\mathrm{a}} \\
(8.81)\end{array}$ & $\begin{array}{l}15.224 \\
(0.17)\end{array}$ & $\begin{array}{l}-0.026^{\mathrm{c}} \\
(-1.68)\end{array}$ & $\begin{array}{l}5.792^{\mathrm{a}} \\
(13.99)\end{array}$ & $\begin{array}{l}2.401^{\mathrm{a}} \\
(5.49)\end{array}$ & $\begin{array}{c}113.26^{\mathrm{a}} \\
(5.23)\end{array}$ \\
\hline $2 c$ & $\begin{array}{l}0.038 \\
(1.05)\end{array}$ & $\begin{array}{l}-1.490 \\
(-0.46)\end{array}$ & $\begin{array}{l}2.030^{\mathrm{a}} \\
(3.28)\end{array}$ & $\begin{array}{c}-96.107 \\
(-0.60)\end{array}$ & $\begin{array}{l}-0.061^{\mathrm{c}} \\
(-1.69)\end{array}$ & $\begin{array}{l}5.076^{a} \\
(9.29)\end{array}$ & $\begin{array}{c}2.818^{\mathrm{a}} \\
(10.51)\end{array}$ & $\begin{array}{c}82.000^{b} \\
(2.25)\end{array}$ \\
\hline $3 a$ & $\begin{array}{l}-0.012^{\mathrm{c}} \\
(-1.67)\end{array}$ & $\begin{array}{l}4.603^{a} \\
(6.34)\end{array}$ & $\begin{array}{c}2.614^{\mathrm{a}} \\
(10.09)\end{array}$ & $\begin{array}{l}-0.337 \\
(-0.43)\end{array}$ & - & - & - & - \\
\hline $3 b$ & $\begin{array}{l}-0.001 \\
(-0.09)\end{array}$ & $\begin{array}{l}2.467^{b} \\
(2.03)\end{array}$ & $\begin{array}{l}2.618^{\mathrm{a}} \\
(8.55)\end{array}$ & $\begin{array}{l}-0.012 \\
(-0.01)\end{array}$ & $\begin{array}{l}-0.007 \\
(-0.53)\end{array}$ & $\begin{array}{l}5.721^{\mathrm{a}} \\
(12.04)\end{array}$ & $\begin{array}{l}2.404^{\mathrm{a}} \\
(5.60)\end{array}$ & $\begin{array}{l}-0.949 \\
(-0.76)\end{array}$ \\
\hline $3 c$ & $\begin{array}{l}0.018 \\
(0.70)\end{array}$ & $\begin{array}{l}-1.145 \\
(-0.35)\end{array}$ & $\begin{array}{l}2.240^{\mathrm{a}} \\
(4.99)\end{array}$ & $\begin{array}{l}1.129 \\
(0.65)\end{array}$ & $\begin{array}{l}-0.027 \\
(-1.04)\end{array}$ & $\begin{array}{l}5.020^{\mathrm{a}} \\
(9.71)\end{array}$ & $\begin{array}{l}2.682^{\mathrm{a}} \\
(9.38)\end{array}$ & $\begin{array}{l}-0.782 \\
(-0.99)\end{array}$ \\
\hline $4 a$ & $\begin{array}{l}-0.021^{\mathrm{a}} \\
(-3.49)\end{array}$ & $\begin{array}{l}4.635^{a} \\
(6.25)\end{array}$ & $\begin{array}{c}2.720^{\mathrm{a}} \\
(11.10)\end{array}$ & $\begin{array}{c}72.948^{\mathrm{c}} \\
(1.92)\end{array}$ & - & - & - & - \\
\hline $4 b$ & $\begin{array}{l}-0.005 \\
(-0.52)\end{array}$ & $\begin{array}{l}2.489^{c} \\
(1.99)\end{array}$ & $\begin{array}{l}2.683^{a} \\
(9.36)\end{array}$ & $\begin{array}{c}39.939 \\
(0.54)\end{array}$ & $\begin{array}{c}-0.021^{\mathrm{c}} \\
(-1.67)\end{array}$ & $\begin{array}{l}5.759^{\mathrm{a}} \\
(12.93)\end{array}$ & $\begin{array}{l}2.418^{\mathrm{a}} \\
(5.65)\end{array}$ & $\begin{array}{c}107.74^{\mathrm{a}} \\
(6.81)\end{array}$ \\
\hline $4 c$ & $\begin{array}{l}0.027 \\
(1.11)\end{array}$ & $\begin{array}{l}-1.325 \\
(-0.44)\end{array}$ & $\begin{array}{l}2.165^{\mathrm{a}} \\
(4.31)\end{array}$ & $\begin{array}{c}-12.730 \\
(-0.11)\end{array}$ & $\begin{array}{l}-0.048^{\mathrm{c}} \\
(-1.95)\end{array}$ & $\begin{array}{l}5.050^{\mathrm{a}} \\
(9.12)\end{array}$ & $\begin{array}{c}2.823^{\mathrm{a}} \\
(10.45)\end{array}$ & $\begin{array}{c}66.947^{c} \\
(1.75)\end{array}$ \\
\hline $5 a$ & $\begin{array}{l}-0.015^{\mathrm{b}} \\
(-2.30)\end{array}$ & $\begin{array}{l}4.636^{a} \\
(7.51)\end{array}$ & $\begin{array}{c}2.642^{\mathrm{a}} \\
(11.35)\end{array}$ & $\begin{array}{l}-0.560 \\
(-0.84)\end{array}$ & - & - & - & - \\
\hline $5 b$ & $\begin{array}{l}-0.006 \\
(-0.51)\end{array}$ & $\begin{array}{l}3.123^{b} \\
(2.31)\end{array}$ & $\begin{array}{c}2.576^{\mathrm{a}} \\
(10.28)\end{array}$ & $\begin{array}{l}-0.461 \\
(-0.57)\end{array}$ & $\begin{array}{l}-0.003 \\
(-0.23)\end{array}$ & $\begin{array}{c}5.398^{\mathrm{a}} \\
(10.98)\end{array}$ & $\begin{array}{l}2.438^{\mathrm{a}} \\
(4.92)\end{array}$ & $\begin{array}{l}-1.377 \\
(-1.11)\end{array}$ \\
\hline $5 c$ & $\begin{array}{l}-0.009 \\
(-0.60)\end{array}$ & $\begin{array}{l}1.639 \\
(0.62)\end{array}$ & $\begin{array}{l}2.426^{\mathrm{a}} \\
(4.80)\end{array}$ & $\begin{array}{l}1.821^{\mathrm{b}} \\
(2.57)\end{array}$ & $\begin{array}{l}-0.001 \\
(-0.04)\end{array}$ & $\begin{array}{l}4.709^{\mathrm{a}} \\
(8.00)\end{array}$ & $\begin{array}{l}2.561^{\mathrm{a}} \\
(9.09)\end{array}$ & $\begin{array}{l}-1.353^{\mathrm{C}} \\
(-1.86)\end{array}$ \\
\hline $6 a$ & $\begin{array}{l}-0.026^{\mathrm{a}} \\
(-4.14)\end{array}$ & $\begin{array}{l}4.684^{\mathrm{a}} \\
(7.77)\end{array}$ & $\begin{array}{c}2.701^{\mathrm{a}} \\
(12.67)\end{array}$ & $\begin{array}{c}61.160^{\mathrm{C}} \\
(1.82)\end{array}$ & - & - & - & - \\
\hline $6 b$ & $\begin{array}{l}-0.012 \\
(-0.85)\end{array}$ & $\begin{array}{l}3.232^{b} \\
(2.37)\end{array}$ & $\begin{array}{l}2.618^{\mathrm{a}} \\
(10.72)\end{array}$ & $\begin{array}{c}13.622 \\
(0.17)\end{array}$ & $\begin{array}{l}-0.021 \\
(-1.28)\end{array}$ & $\begin{array}{c}5.424^{\mathrm{a}} \\
(10.92)\end{array}$ & $\begin{array}{l}2.390^{\mathrm{a}} \\
(4.58)\end{array}$ & $\begin{array}{c}104.34^{\mathrm{a}} \\
(3.18)\end{array}$ \\
\hline $6 c$ & $\begin{array}{l}0.003 \\
(0.11)\end{array}$ & $\begin{array}{l}1.503 \\
(0.52)\end{array}$ & $\begin{array}{l}2.584^{a} \\
(4.92)\end{array}$ & $\begin{array}{l}19.582 \\
(0.19)\end{array}$ & $\begin{array}{l}-0.030 \\
(-1.18)\end{array}$ & $\begin{array}{l}4.823^{a} \\
(8.69)\end{array}$ & $\begin{array}{c}2.670^{\mathrm{a}} \\
(10.45)\end{array}$ & $\begin{array}{l}62.757 \\
(1.65)\end{array}$ \\
\hline $7 a$ & $\begin{array}{l}-0.013^{\mathrm{b}} \\
(-2.01)\end{array}$ & $\begin{array}{l}4.599^{a} \\
(7.56)\end{array}$ & $\begin{array}{c}2.600^{\mathrm{a}} \\
(11.26)\end{array}$ & $\begin{array}{l}-0.846 \\
(-1.42)\end{array}$ & - & - & - & - \\
\hline $7 b$ & $\begin{array}{l}-0.006 \\
(-0.53)\end{array}$ & $\begin{array}{l}3.161^{b} \\
(2.39)\end{array}$ & $\begin{array}{c}2.553^{\mathrm{a}} \\
(10.53)\end{array}$ & $\begin{array}{l}-0.524 \\
(-0.75)\end{array}$ & $\begin{array}{l}0.003 \\
(0.16)\end{array}$ & $\begin{array}{l}5.204^{\mathrm{a}} \\
(9.55)\end{array}$ & $\begin{array}{l}2.408^{\mathrm{a}} \\
(5.14)\end{array}$ & $\begin{array}{l}-2.277 \\
(-1.56)\end{array}$ \\
\hline $7 c$ & $\begin{array}{l}-0.002 \\
(-0.12)\end{array}$ & $\begin{array}{l}0.971 \\
(0.36)\end{array}$ & $\begin{array}{l}2.626^{\mathrm{a}} \\
(5.05)\end{array}$ & $\begin{array}{l}1.531^{\mathrm{C}} \\
(1.88)\end{array}$ & $\begin{array}{l}-0.007 \\
(-0.46)\end{array}$ & $\begin{array}{l}4.646^{\mathrm{a}} \\
(8.03)\end{array}$ & $\begin{array}{l}2.549^{a} \\
(9.26)\end{array}$ & $\begin{array}{c}-1.522^{b} \\
(-2.24)\end{array}$ \\
\hline $8 a$ & $\begin{array}{l}-0.023^{\mathrm{a}} \\
(-3.75)\end{array}$ & $\begin{array}{l}4.674^{\mathrm{a}} \\
(7.75)\end{array}$ & $\begin{array}{c}2.705^{\mathrm{a}} \\
(12.37)\end{array}$ & $\begin{array}{c}34.083 \\
(1.21)\end{array}$ & - & - & - & - \\
\hline $8 b$ & $\begin{array}{l}-0.012 \\
(-0.99)\end{array}$ & $\begin{array}{l}3.231^{b} \\
(2.36)\end{array}$ & $\begin{array}{c}2.640^{\mathrm{a}} \\
(10.60)\end{array}$ & $\begin{array}{l}15.956 \\
(0.40)\end{array}$ & $\begin{array}{l}-0.025 \\
(-1.65)\end{array}$ & $\begin{array}{c}5.507^{\mathrm{a}} \\
(11.36)\end{array}$ & $\begin{array}{l}2.212^{\mathrm{a}} \\
(4.38)\end{array}$ & $\begin{array}{c}145.69^{\mathrm{a}} \\
(3.28)\end{array}$ \\
\hline $8 c$ & $\begin{array}{l}0.004 \\
(0.18)\end{array}$ & $\begin{array}{l}1.517 \\
(0.54)\end{array}$ & $\begin{array}{l}2.558^{a} \\
(5.24)\end{array}$ & $\begin{array}{l}10.129 \\
(0.21)\end{array}$ & $\begin{array}{l}-0.028 \\
(-1.29)\end{array}$ & $\begin{array}{l}4.822^{a} \\
(8.72)\end{array}$ & $\begin{array}{c}9.669^{\mathrm{a}} \\
(10.28)\end{array}$ & $\begin{array}{c}37.561 \\
(0.95) \\
\end{array}$ \\
\hline
\end{tabular}

Notes:

(i) $t$-statistics in parentheses; ${ }^{a}$, ${ }^{b}$ and ${ }^{c}$ denote significance at the $1 \%, 5 \%$ and $10 \%$ levels, respectively.

(ii) Equations denoted with $b$ and $c$ include a dummy variable, equal to 1 after 2008:4 and 1999:1, respectively.

(iii) LREER is LREER_EXP in Equations 1 to 4; and LREER_ULC in Equations 5 to 8.

(iv) Volatility is VNEER1, VNEER2, VREER_EXP1 and VREER_EXP2 in Equations 1 to 4; and VNEER1, VNEER2, $V R E E R \_U L C 1$ and VREER_ULC2 in Equations 5 to 8. 
Economics: The Open-Access, Open-Assessment E-Journal 14 (2020-5)

Table 7: Exports and exchange rate volatility: Germany

\begin{tabular}{|c|c|c|c|c|c|c|c|c|}
\hline Equation & constant & $\Delta L Y^{*}$ & $\triangle L R E E R$ & volatility & constant & $\Delta L Y^{*}$ & $\triangle L R E E R$ & volatility \\
\hline $1 a$ & $\begin{array}{l}-0.011 \\
(-1.41)\end{array}$ & $\begin{array}{l}6.573^{\mathrm{a}} \\
(6.62)\end{array}$ & $\begin{array}{l}2.272^{\mathrm{a}} \\
(8.44)\end{array}$ & $\begin{array}{l}-0.967^{\mathrm{a}} \\
(-2.07)\end{array}$ & - & - & - & - \\
\hline $1 b$ & $\begin{array}{l}0.014 \\
(1.42)\end{array}$ & $\begin{array}{l}2.996^{\mathrm{a}} \\
(3.01)\end{array}$ & $\begin{array}{l}2.225^{\mathrm{a}} \\
(7.40)\end{array}$ & $\begin{array}{l}-1.188^{\mathrm{a}} \\
(-2.57)\end{array}$ & $\begin{array}{c}-0.031^{\mathrm{a}} \\
(-2.20)\end{array}$ & $\begin{array}{c}8.031^{\mathrm{a}} \\
(15.22)\end{array}$ & $\begin{array}{l}1.956^{\mathrm{a}} \\
(5.30)\end{array}$ & $\begin{array}{l}-0.810 \\
(-0.80)\end{array}$ \\
\hline $1 c$ & $\begin{array}{l}0.006 \\
(0.80)\end{array}$ & $\begin{array}{l}0.058 \\
(0.07)\end{array}$ & $\begin{array}{l}1.838^{\mathrm{a}} \\
(5.80)\end{array}$ & $\begin{array}{l}0.810^{c} \\
(1.73)\end{array}$ & $\begin{array}{l}-0.017 \\
(-1.64)\end{array}$ & $\begin{array}{l}7.217^{\mathrm{a}} \\
(9.00)\end{array}$ & $\begin{array}{l}2.342^{\mathrm{a}} \\
(8.47)\end{array}$ & $\begin{array}{l}-0.777 \\
(-1.31)\end{array}$ \\
\hline $2 a$ & $\begin{array}{l}-0.005 \\
(-0.52)\end{array}$ & $\begin{array}{l}6.764^{\mathrm{a}} \\
(6.95)\end{array}$ & $\begin{array}{l}2.385^{\mathrm{a}} \\
(9.32)\end{array}$ & $\begin{array}{c}-104.88^{\mathrm{a}} \\
(-2.27)\end{array}$ & - & - & - & - \\
\hline $2 b$ & $\begin{array}{l}0.017 \\
(1.60)\end{array}$ & $\begin{array}{l}3.286^{\mathrm{a}} \\
(3.27)\end{array}$ & $\begin{array}{l}2.335^{\mathrm{a}} \\
(7.99)\end{array}$ & $\begin{array}{c}-92.743^{\mathrm{a}} \\
(-2.27)\end{array}$ & $\begin{array}{l}0.046 \\
(0.91)\end{array}$ & $\begin{array}{c}8.072^{\mathrm{a}} \\
(14.88)\end{array}$ & $\begin{array}{l}2.121^{\mathrm{a}} \\
(7.29)\end{array}$ & $\begin{array}{r}-766.49^{\mathrm{c}} \\
(-1.83)\end{array}$ \\
\hline $2 c$ & $\begin{array}{l}-0.009 \\
(-0.72)\end{array}$ & $\begin{array}{l}-0.157 \\
(-0.17)\end{array}$ & $\begin{array}{l}1.668^{\mathrm{a}} \\
(5.61)\end{array}$ & $\begin{array}{c}110.16^{\mathrm{b}} \\
(2.59)\end{array}$ & $\begin{array}{l}0.006 \\
(0.34)\end{array}$ & $\begin{array}{l}7.212^{\mathrm{a}} \\
(8.69)\end{array}$ & $\begin{array}{l}2.381^{\mathrm{a}} \\
(9.41)\end{array}$ & $\begin{array}{c}-121.95 \\
(-1.40)\end{array}$ \\
\hline $3 a$ & $\begin{array}{l}-0.006 \\
(-0.82)\end{array}$ & $\begin{array}{l}6.702^{\mathrm{a}} \\
(7.59)\end{array}$ & $\begin{array}{l}2.218^{\mathrm{a}} \\
(8.27)\end{array}$ & $\begin{array}{l}-1.652^{\mathrm{a}} \\
(-2.24)\end{array}$ & - & - & - & - \\
\hline $3 b$ & $\begin{array}{l}0.016^{\mathrm{a}} \\
(1.97)\end{array}$ & $\begin{array}{l}3.670^{\mathrm{a}} \\
(4.69)\end{array}$ & $\begin{array}{l}2.188^{\mathrm{a}} \\
(7.05)\end{array}$ & $\begin{array}{l}-2.044^{\mathrm{a}} \\
(-3.36)\end{array}$ & $\begin{array}{l}-0.039^{\mathrm{a}} \\
(-3.37)\end{array}$ & $\begin{array}{c}8.063^{\mathrm{a}} \\
(14.65)\end{array}$ & $\begin{array}{l}2.002^{\mathrm{a}} \\
(4.84)\end{array}$ & $\begin{array}{l}0.095 \\
(0.14)\end{array}$ \\
\hline $3 c$ & $\begin{array}{l}0.013^{\mathrm{a}} \\
(2.17)\end{array}$ & $\begin{array}{l}0.048 \\
(0.04)\end{array}$ & $\begin{array}{l}1.907^{\mathrm{a}} \\
(5.85)\end{array}$ & $\begin{array}{l}0.170 \\
(0.24)\end{array}$ & $\begin{array}{l}-0.020^{\mathrm{c}} \\
(-1.91)\end{array}$ & $\begin{array}{c}7.273^{\mathrm{a}} \\
(10.19)\end{array}$ & $\begin{array}{l}2.283^{\mathrm{a}} \\
(8.64)\end{array}$ & $\begin{array}{l}-1.451 \\
(-1.62)\end{array}$ \\
\hline $4 a$ & $\begin{array}{l}-0.019 \\
(-1.45)\end{array}$ & $\begin{array}{l}6.552^{\mathrm{a}} \\
(6.12)\end{array}$ & $\begin{array}{l}2.268^{\mathrm{a}} \\
(8.45)\end{array}$ & $\begin{array}{l}6.004 \\
(0.07)\end{array}$ & - & - & - & - \\
\hline $4 b$ & $\begin{array}{l}0.022^{\mathrm{a}} \\
(2.24)\end{array}$ & $\begin{array}{l}3.593^{\mathrm{a}} \\
(3.99)\end{array}$ & $\begin{array}{l}2.252^{\mathrm{a}} \\
(7.62)\end{array}$ & $\begin{array}{c}-124.37^{\mathrm{a}} \\
(-2.58)\end{array}$ & $\begin{array}{l}-0.081^{\mathrm{a}} \\
(-6.57)\end{array}$ & $\begin{array}{c}7.043^{\mathrm{a}} \\
(12.99)\end{array}$ & $\begin{array}{l}1.668^{\mathrm{a}} \\
(7.07)\end{array}$ & $\begin{array}{c}266.91^{\mathrm{a}} \\
(6.65)\end{array}$ \\
\hline $4 c$ & $\begin{array}{l}-0.023 \\
(-0.58)\end{array}$ & $\begin{array}{l}0.867 \\
(0.57)\end{array}$ & $\begin{array}{l}1.985^{\mathrm{a}} \\
(7.33)\end{array}$ & $\begin{array}{l}143.74 \\
(1.09)\end{array}$ & $\begin{array}{l}0.001 \\
(0.02)\end{array}$ & $\begin{array}{l}7.156^{\mathrm{a}} \\
(8.71)\end{array}$ & $\begin{array}{l}2.372^{\mathrm{a}} \\
(8.63)\end{array}$ & $\begin{array}{l}43.164 \\
(0.44)\end{array}$ \\
\hline $5 a$ & $\begin{array}{l}-0.012^{\mathrm{b}} \\
(-1.68)\end{array}$ & $\begin{array}{l}7.169^{\mathrm{a}} \\
(6.99)\end{array}$ & $\begin{array}{l}2.071^{\mathrm{a}} \\
(8.73)\end{array}$ & $\begin{array}{l}-1.160^{\mathrm{a}} \\
(-2.49)\end{array}$ & - & - & - & - \\
\hline $5 b$ & $\begin{array}{l}0.018^{\mathrm{a}} \\
(2.30)\end{array}$ & $\begin{array}{l}3.393^{\mathrm{a}} \\
(4.31)\end{array}$ & $\begin{array}{l}2.081^{\mathrm{a}} \\
(8.99)\end{array}$ & $\begin{array}{l}-1.532^{\mathrm{a}} \\
(-4.07)\end{array}$ & $\begin{array}{l}-0.039^{\mathrm{a}} \\
(-3.24)\end{array}$ & $\begin{array}{c}8.294^{\mathrm{a}} \\
(13.69)\end{array}$ & $\begin{array}{l}1.729^{\mathrm{a}} \\
(4.69)\end{array}$ & $\begin{array}{l}-0.945 \\
(-0.89)\end{array}$ \\
\hline $5 c$ & $\begin{array}{l}0.009 \\
(1.64)\end{array}$ & $\begin{array}{l}1.024 \\
(1.14)\end{array}$ & $\begin{array}{l}1.625^{\mathrm{a}} \\
(7.18)\end{array}$ & $\begin{array}{l}0.120 \\
(0.26)\end{array}$ & $\begin{array}{l}-0.023^{\mathrm{b}} \\
(-2.53)\end{array}$ & $\begin{array}{l}7.682^{\mathrm{a}} \\
(8.45)\end{array}$ & $\begin{array}{l}2.110^{\mathrm{a}} \\
(6.48)\end{array}$ & $\begin{array}{l}-0.931 \\
(-1.46)\end{array}$ \\
\hline $6 a$ & $\begin{array}{l}-0.008 \\
(-0.99)\end{array}$ & $\begin{array}{l}7.372^{\mathrm{a}} \\
(7.25)\end{array}$ & $\begin{array}{l}2.155^{\mathrm{a}} \\
(8.74)\end{array}$ & $\begin{array}{c}-103.23^{\mathrm{a}} \\
(-2.70)\end{array}$ & - & - & - & - \\
\hline $6 b$ & $\begin{array}{l}0.019^{\mathrm{a}} \\
(2.48)\end{array}$ & $\begin{array}{l}3.743^{\mathrm{a}} \\
(4.70)\end{array}$ & $\begin{array}{l}2.181^{\mathrm{a}} \\
(9.26)\end{array}$ & $\begin{array}{c}-108.47^{\mathrm{a}} \\
(-3.46)\end{array}$ & $\begin{array}{l}0.041 \\
(0.08)\end{array}$ & $\begin{array}{c}8.380^{\mathrm{a}} \\
(13.75)\end{array}$ & $\begin{array}{l}1.909^{\mathrm{a}} \\
(6.39)\end{array}$ & $\begin{array}{r}-813.62^{\mathrm{C}} \\
(-1.79)\end{array}$ \\
\hline $6 c$ & $\begin{array}{l}0.001 \\
(0.10)\end{array}$ & $\begin{array}{l}0.768 \\
(0.79)\end{array}$ & $\begin{array}{l}1.514^{\mathrm{a}} \\
(5.86)\end{array}$ & $\begin{array}{l}48.690 \\
(1.04)\end{array}$ & $\begin{array}{l}-0.011 \\
(-0.60)\end{array}$ & $\begin{array}{l}7.711^{\mathrm{a}} \\
(8.29)\end{array}$ & $\begin{array}{l}2.142^{\mathrm{a}} \\
(6.73)\end{array}$ & $\begin{array}{r}-93.172 \\
(-0.79)\end{array}$ \\
\hline $7 a$ & $\begin{array}{c}-0.015^{\mathrm{c}} \\
(-1.79)\end{array}$ & $\begin{array}{l}7.409^{\mathrm{a}} \\
(7.39)\end{array}$ & $\begin{array}{l}2.051^{\mathrm{a}} \\
(8.97)\end{array}$ & $\begin{array}{l}-0.955 \\
(-1.60)\end{array}$ & - & - & - & - \\
\hline $7 b$ & $\begin{array}{l}0.014^{\mathrm{C}} \\
(1.77)\end{array}$ & $\begin{array}{l}3.929^{\mathrm{a}} \\
(4.72)\end{array}$ & $\begin{array}{l}2.022^{\mathrm{a}} \\
(8.85)\end{array}$ & $\begin{array}{c}-1.403^{\mathrm{b}} \\
(2.39)\end{array}$ & $\begin{array}{l}-0.044^{\mathrm{a}} \\
(-3.91)\end{array}$ & $\begin{array}{c}8.281^{\mathrm{a}} \\
(14.05)\end{array}$ & $\begin{array}{l}1.760^{\mathrm{a}} \\
(4.34)\end{array}$ & $\begin{array}{l}0.020 \\
(0.29)\end{array}$ \\
\hline $7 c$ & $\begin{array}{l}0.008 \\
(1.43)\end{array}$ & $\begin{array}{l}0.705 \\
(0.59)\end{array}$ & $\begin{array}{l}1.623^{\mathrm{a}} \\
(8.09)\end{array}$ & $\begin{array}{l}0.407 \\
(0.59)\end{array}$ & $\begin{array}{l}-0.023^{\mathrm{b}} \\
(-2.24)\end{array}$ & $\begin{array}{l}7.919^{\mathrm{a}} \\
(9.23)\end{array}$ & $\begin{array}{l}2.144^{\mathrm{a}} \\
(6.94)\end{array}$ & $\begin{array}{l}-0.847 \\
(-1.03)\end{array}$ \\
\hline $8 a$ & $\begin{array}{l}-0.026 \\
(-1.54)\end{array}$ & $\begin{array}{l}7.088^{\mathrm{a}} \\
(6.65)\end{array}$ & $\begin{array}{l}2.047^{\mathrm{a}} \\
(8.68)\end{array}$ & $\begin{array}{l}22.764 \\
(0.29)\end{array}$ & - & - & - & - \\
\hline $8 b$ & $\begin{array}{l}0.023^{c} \\
(1.70)\end{array}$ & $\begin{array}{l}3.724^{\mathrm{a}} \\
(4.25)\end{array}$ & $\begin{array}{l}2.054^{\mathrm{a}} \\
(8.80)\end{array}$ & $\begin{array}{c}-94.309 \\
(-1.60)\end{array}$ & $\begin{array}{l}-0.113^{\mathrm{a}} \\
(-5.16)\end{array}$ & $\begin{array}{c}7.286^{\mathrm{a}} \\
(10.47)\end{array}$ & $\begin{array}{l}1.558^{\mathrm{a}} \\
(5.12)\end{array}$ & $\begin{array}{c}339.68^{\mathrm{a}} \\
(3.85)\end{array}$ \\
\hline $8 c$ & $\begin{array}{l}-0.020 \\
(-0.59) \\
\end{array}$ & $\begin{array}{l}1.574 \\
(1.32) \\
\end{array}$ & $\begin{array}{c}1.657^{\mathrm{a}} \\
(10.35)\end{array}$ & $\begin{array}{l}101.60 \\
(0.97)\end{array}$ & $\begin{array}{l}-0.016 \\
(-0.40) \\
\end{array}$ & $\begin{array}{l}7.588^{\mathrm{a}} \\
(8.56) \\
\end{array}$ & $\begin{array}{l}2.141^{\mathrm{a}} \\
(6.84)\end{array}$ & $\begin{array}{c}87.884 \\
(0.77) \\
\end{array}$ \\
\hline
\end{tabular}

Notes: See Table 6. 
Economics: The Open-Access, Open-Assessment E-Journal 14 (2020-5)

Table 8: Exports and exchange rate volatility: Italy

\begin{tabular}{|c|c|c|c|c|c|c|c|c|}
\hline Equation & constant & $\Delta L Y^{*}$ & $\triangle L R E E R$ & volatility & constant & $\Delta L Y^{*}$ & $\triangle L R E E R$ & volatility \\
\hline $1 a$ & $\begin{array}{l}-0.021^{b} \\
(-2.40)\end{array}$ & $\begin{array}{l}5.735^{\mathrm{a}} \\
(4.53)\end{array}$ & $\begin{array}{l}1.330^{\mathrm{a}} \\
(3.33)\end{array}$ & $\begin{array}{l}-0.549 \\
(-1.10)\end{array}$ & - & - & - & - \\
\hline $1 b$ & $\begin{array}{l}-0.001 \\
(-0.09)\end{array}$ & $\begin{array}{l}2.280^{c} \\
(1.78)\end{array}$ & $\begin{array}{l}1.154^{\mathrm{a}} \\
(3.12)\end{array}$ & $\begin{array}{l}-0.427 \\
(-0.84)\end{array}$ & $\begin{array}{l}-0.024 \\
(-1.64)\end{array}$ & $\begin{array}{c}8.111^{\mathrm{a}} \\
(13.13)\end{array}$ & $\begin{array}{l}2.550^{\mathrm{a}} \\
(5.23)\end{array}$ & $\begin{array}{l}-0.267 \\
(-0.20)\end{array}$ \\
\hline $1 c$ & $\begin{array}{l}-0.029^{\mathrm{c}} \\
(-1.70)\end{array}$ & $\begin{array}{l}2.682 \\
(1.36)\end{array}$ & $\begin{array}{l}0.508 \\
(1.64)\end{array}$ & $\begin{array}{l}0.800^{c} \\
(1.91)\end{array}$ & $\begin{array}{l}0.007 \\
(0.37)\end{array}$ & $\begin{array}{l}6.797^{a} \\
(7.37)\end{array}$ & $\begin{array}{l}2.513^{\mathrm{a}} \\
(8.93)\end{array}$ & $\begin{array}{l}-0.914 \\
(-1.02)\end{array}$ \\
\hline $2 a$ & $\begin{array}{l}-0.025^{\mathrm{a}} \\
(-3.03)\end{array}$ & $\begin{array}{l}5.693^{\mathrm{a}} \\
(4.41)\end{array}$ & $\begin{array}{l}1.297^{\mathrm{a}} \\
(3.06)\end{array}$ & $\begin{array}{l}-0.676 \\
(-0.04)\end{array}$ & - & - & - & - \\
\hline $2 b$ & $\begin{array}{l}-0.005 \\
(-0.46)\end{array}$ & $\begin{array}{l}2.292^{\mathrm{C}} \\
(1.80)\end{array}$ & $\begin{array}{l}1.125^{\mathrm{a}} \\
(2.95)\end{array}$ & $\begin{array}{l}-0.856 \\
(-0.05)\end{array}$ & $\begin{array}{l}-0.053^{\mathrm{a}} \\
(-3.59)\end{array}$ & $\begin{array}{c}7.375^{\mathrm{a}} \\
(12.31)\end{array}$ & $\begin{array}{l}1.919^{\mathrm{a}} \\
(4.16)\end{array}$ & $\begin{array}{c}227.09^{\mathrm{a}} \\
(9.35)\end{array}$ \\
\hline $2 c$ & $\begin{array}{l}-0.044^{\mathrm{a}} \\
(-2.78)\end{array}$ & $\begin{array}{l}3.678^{b} \\
(2.10)\end{array}$ & $\begin{array}{l}0.397 \\
(1.40)\end{array}$ & $\begin{array}{c}38.980^{b} \\
(2.54)\end{array}$ & $\begin{array}{l}0.013 \\
(0.65)\end{array}$ & $\begin{array}{l}6.861^{\mathrm{a}} \\
(7.83)\end{array}$ & $\begin{array}{l}2.551^{\mathrm{a}} \\
(8.18)\end{array}$ & $\begin{array}{c}20.827 \\
(0.21)\end{array}$ \\
\hline $3 a$ & $\begin{array}{l}-0.021^{\mathrm{b}} \\
(-2.50)\end{array}$ & $\begin{array}{l}5.764^{\mathrm{a}} \\
(4.56)\end{array}$ & $\begin{array}{l}1.335^{\mathrm{a}} \\
(3.45)\end{array}$ & $\begin{array}{l}-0.613 \\
(-1.37)\end{array}$ & - & - & - & - \\
\hline $3 b$ & $\begin{array}{l}-0.000 \\
(-0.03)\end{array}$ & $\begin{array}{l}2.328^{c} \\
(1.82)\end{array}$ & $\begin{array}{l}1.171^{\mathrm{a}} \\
(3.23)\end{array}$ & $\begin{array}{l}-0.585 \\
(-1.09)\end{array}$ & $\begin{array}{c}-0.029^{\mathrm{a}} \\
(-2.25)\end{array}$ & $\begin{array}{l}8.120^{\mathrm{a}} \\
(13.75)\end{array}$ & $\begin{array}{l}2.600^{\mathrm{a}} \\
(5.27)\end{array}$ & $\begin{array}{l}0.464 \\
(0.54)\end{array}$ \\
\hline $3 c$ & $\begin{array}{l}-0.024 \\
(-1.48)\end{array}$ & $\begin{array}{l}2.455 \\
(1.24)\end{array}$ & $\begin{array}{l}0.500 \\
(1.49)\end{array}$ & $\begin{array}{l}0.780^{c} \\
(1.69)\end{array}$ & $\begin{array}{l}0.001 \\
(0.03)\end{array}$ & $\begin{array}{l}6.884^{a} \\
(7.79)\end{array}$ & $\begin{array}{l}2.530^{\mathrm{a}} \\
(9.24)\end{array}$ & $\begin{array}{l}-0.721 \\
(-0.87)\end{array}$ \\
\hline $4 a$ & $\begin{array}{l}-0.029^{b} \\
(-3.23)\end{array}$ & $\begin{array}{l}5.587^{\mathrm{a}} \\
(4.30)\end{array}$ & $\begin{array}{l}1.243^{\mathrm{a}} \\
(3.04)\end{array}$ & $\begin{array}{l}18.730 \\
(0.66)\end{array}$ & - & - & - & - \\
\hline $4 b$ & $\begin{array}{l}-0.005 \\
(-0.47)\end{array}$ & $\begin{array}{l}2.281^{\mathrm{C}} \\
(1.78)\end{array}$ & $\begin{array}{l}1.120^{\mathrm{a}} \\
(2.95)\end{array}$ & $\begin{array}{l}0.630 \\
(0.03)\end{array}$ & $\begin{array}{c}-0.039^{\mathrm{a}} \\
(-3.09)\end{array}$ & $\begin{array}{c}7.624^{\mathrm{a}} \\
(12.93)\end{array}$ & $\begin{array}{l}2.222^{\mathrm{a}} \\
(5.46)\end{array}$ & $\begin{array}{c}116.07^{\mathrm{a}} \\
(4.99)\end{array}$ \\
\hline $4 c$ & $\begin{array}{l}-0.046^{\mathrm{a}} \\
(-2.71)\end{array}$ & $\begin{array}{l}3.916^{\mathrm{b}} \\
(2.09)\end{array}$ & $\begin{array}{l}0.360 \\
(1.19)\end{array}$ & $\begin{array}{c}61.000^{\mathrm{b}} \\
(2.36)\end{array}$ & $\begin{array}{l}0.010 \\
(0.52)\end{array}$ & $\begin{array}{l}6.725^{\mathrm{a}} \\
(7.43)\end{array}$ & $\begin{array}{l}2.521^{\mathrm{a}} \\
(8.49)\end{array}$ & $\begin{array}{l}56.821 \\
(1.13)\end{array}$ \\
\hline $5 a$ & $\begin{array}{l}-0.020^{\mathrm{b}} \\
(-2.20)\end{array}$ & $\begin{array}{l}5.579^{a} \\
(4.21)\end{array}$ & $\begin{array}{l}0.892^{a} \\
(2.79)\end{array}$ & $\begin{array}{l}-0.465 \\
(-0.81)\end{array}$ & - & - & - & - \\
\hline $5 b$ & $\begin{array}{l}0.001 \\
(0.09)\end{array}$ & $\begin{array}{l}2.093 \\
(1.64)\end{array}$ & $\begin{array}{l}0.746^{a} \\
(2.86)\end{array}$ & $\begin{array}{l}-0.347 \\
(-0.64)\end{array}$ & $\begin{array}{c}-0.025^{\mathrm{c}} \\
(-1.80)\end{array}$ & $\begin{array}{c}7.930^{\mathrm{a}} \\
(11.97)\end{array}$ & $\begin{array}{l}2.625^{\mathrm{a}} \\
(4.32)\end{array}$ & $\begin{array}{l}-0.655 \\
(-0.50)\end{array}$ \\
\hline $5 c$ & $\begin{array}{l}-0.022 \\
(-1.00)\end{array}$ & $\begin{array}{l}2.187 \\
(0.85)\end{array}$ & $\begin{array}{l}0.303 \\
(1.19)\end{array}$ & $\begin{array}{l}0.780^{\mathrm{c}} \\
(1.70)\end{array}$ & $\begin{array}{l}0.002 \\
(0.08)\end{array}$ & $\begin{array}{l}6.681^{a} \\
(7.53)\end{array}$ & $\begin{array}{l}2.263^{\mathrm{a}} \\
(8.37)\end{array}$ & $\begin{array}{l}-1.406 \\
(-1.44)\end{array}$ \\
\hline $6 a$ & $\begin{array}{l}-0.025^{\mathrm{a}} \\
(-2.85)\end{array}$ & $\begin{array}{l}5.512^{\mathrm{a}} \\
(4.11)\end{array}$ & $\begin{array}{l}0.864^{\mathrm{a}} \\
(2.73)\end{array}$ & $\begin{array}{l}4.407 \\
(0.24)\end{array}$ & - & - & - & - \\
\hline $6 b$ & $\begin{array}{l}-0.003 \\
(-0.30)\end{array}$ & $\begin{array}{l}2.082 \\
(1.65)\end{array}$ & $\begin{array}{l}0.726^{\mathrm{a}} \\
(2.84)\end{array}$ & $\begin{array}{l}2.713 \\
(0.16)\end{array}$ & $\begin{array}{l}-0.055^{\mathrm{a}} \\
(-4.06)\end{array}$ & $\begin{array}{l}7.273^{\mathrm{a}} \\
(11.73)\end{array}$ & $\begin{array}{l}2.003^{\mathrm{a}} \\
(3.63)\end{array}$ & $\begin{array}{c}218.31^{\mathrm{a}} \\
(4.63)\end{array}$ \\
\hline $6 c$ & $\begin{array}{l}-0.043^{\mathrm{C}} \\
(-1.69)\end{array}$ & $\begin{array}{l}3.706 \\
(1.48)\end{array}$ & $\begin{array}{l}0.168 \\
(0.73)\end{array}$ & $\begin{array}{c}39.774^{\mathrm{b}} \\
(2.18)\end{array}$ & $\begin{array}{l}0.004 \\
(0.15)\end{array}$ & $\begin{array}{l}6.720^{\mathrm{a}} \\
(8.49)\end{array}$ & $\begin{array}{l}2.287^{\mathrm{a}} \\
(8.04)\end{array}$ & $\begin{array}{l}65.773 \\
(0.78)\end{array}$ \\
\hline $7 a$ & $\begin{array}{l}-0.020^{\mathrm{b}} \\
(-2.17)\end{array}$ & $\begin{array}{l}5.633^{a} \\
(4.23)\end{array}$ & $\begin{array}{l}0.900^{\mathrm{a}} \\
(2.73)\end{array}$ & $\begin{array}{l}-0.419 \\
(-0.84)\end{array}$ & - & - & - & - \\
\hline $7 b$ & $\begin{array}{l}0.002 \\
(0.18)\end{array}$ & $\begin{array}{l}2.104 \\
(1.65)\end{array}$ & $\begin{array}{l}0.754^{\mathrm{a}} \\
(2.80)\end{array}$ & $\begin{array}{l}-0.365 \\
(-0.80)\end{array}$ & $\begin{array}{l}-0.026^{\mathrm{c}} \\
(-1.93)\end{array}$ & $\begin{array}{c}7.993^{\mathrm{a}} \\
(12.98)\end{array}$ & $\begin{array}{l}2.642^{\mathrm{a}} \\
(4.37)\end{array}$ & $\begin{array}{l}-0.509 \\
(-0.41)\end{array}$ \\
\hline $7 c$ & $\begin{array}{l}-0.031 \\
(-1.15)\end{array}$ & $\begin{array}{l}2.837 \\
(0.96)\end{array}$ & $\begin{array}{l}0.254 \\
(0.92)\end{array}$ & $\begin{array}{l}0.818^{\mathrm{C}} \\
(1.83)\end{array}$ & $\begin{array}{l}0.010 \\
(0.35)\end{array}$ & $\begin{array}{l}6.851^{\mathrm{a}} \\
(8.10)\end{array}$ & $\begin{array}{l}2.290^{\mathrm{a}} \\
(9.06)\end{array}$ & $\begin{array}{l}-1.259 \\
(-1.47)\end{array}$ \\
\hline $8 a$ & $\begin{array}{l}-0.026^{\mathrm{a}} \\
(-2.84)\end{array}$ & $\begin{array}{l}5.483^{\mathrm{a}} \\
(4.10)\end{array}$ & $\begin{array}{l}0.893^{\mathrm{a}} \\
(3.16)\end{array}$ & $\begin{array}{l}8.625 \\
(0.52)\end{array}$ & - & - & - & - \\
\hline $8 b$ & $\begin{array}{l}-0.007 \\
(-0.58)\end{array}$ & 2.084 & $\begin{array}{l}0.764^{\mathrm{a}} \\
(3.67)\end{array}$ & $\begin{array}{c}11.434 \\
(0.73)\end{array}$ & $\begin{array}{l}-0.032 \\
(-0.78)\end{array}$ & $\begin{array}{c}8.044^{\mathrm{a}} \\
(11.11)\end{array}$ & $\begin{array}{l}2.640^{\mathrm{a}} \\
(4.29)\end{array}$ & $\begin{array}{l}107.32 \\
(0.29)\end{array}$ \\
\hline $8 c$ & $\begin{array}{l}-0.051^{\mathrm{b}} \\
(-2.17)\end{array}$ & $\begin{array}{l}3.419^{c} \\
(1.83)\end{array}$ & $\begin{array}{l}0.436^{\mathrm{a}} \\
(5.01)\end{array}$ & $\begin{array}{c}45.144^{\mathrm{a}} \\
(3.50)\end{array}$ & $\begin{array}{l}0.030 \\
(1.21)\end{array}$ & $\begin{array}{l}6.876^{\mathrm{a}} \\
(8.17)\end{array}$ & $\begin{array}{l}2.303^{\mathrm{a}} \\
(8.59)\end{array}$ & $\begin{array}{c}-61.721^{\mathrm{c}} \\
(-1.85)\end{array}$ \\
\hline
\end{tabular}

Notes: See Table 6. 
Economics: The Open-Access, Open-Assessment E-Journal 14 (2020-5)

Table 9: Exports and exchange rate volatility: Spain

\begin{tabular}{|c|c|c|c|c|c|c|c|c|}
\hline Equation & constant & $\Delta L Y^{*}$ & $\triangle L R E E R$ & volatility & constant & $\Delta L Y^{*}$ & $\triangle L R E E R$ & volatility \\
\hline $1 a$ & $\begin{array}{l}-0.012 \\
(-0.83)\end{array}$ & $\begin{array}{l}5.414^{\mathrm{a}} \\
(3.26)\end{array}$ & $\begin{array}{l}3.089^{\mathrm{a}} \\
(4.21)\end{array}$ & $\begin{array}{l}-1.837^{\mathrm{c}} \\
(-1.83)\end{array}$ & - & - & - & - \\
\hline $1 b$ & $\begin{array}{l}0.020 \\
(0.95)\end{array}$ & $\begin{array}{l}0.566 \\
(0.33)\end{array}$ & $\begin{array}{l}3.042^{\mathrm{a}} \\
(3.29)\end{array}$ & $\begin{array}{l}-2.757^{\mathrm{a}} \\
(-2.90)\end{array}$ & $\begin{array}{l}-0.044^{\mathrm{c}} \\
(-1.83)\end{array}$ & $\begin{array}{l}9.081^{\mathrm{a}} \\
(7.46)\end{array}$ & $\begin{array}{l}5.223^{\mathrm{a}} \\
(3.89)\end{array}$ & $\begin{array}{l}1.505 \\
(0.77)\end{array}$ \\
\hline $1 c$ & $\begin{array}{l}0.070 \\
(1.17)\end{array}$ & $\begin{array}{l}-5.361 \\
(-1.04)\end{array}$ & $\begin{array}{l}2.312 \\
(1.51)\end{array}$ & $\begin{array}{l}-2.465 \\
(-1.28)\end{array}$ & $\begin{array}{l}-0.095 \\
(-1.55)\end{array}$ & $\begin{array}{l}6.275^{\mathrm{a}} \\
(4.43)\end{array}$ & $\begin{array}{l}3.772^{\mathrm{a}} \\
(5.90)\end{array}$ & $\begin{array}{l}-0.038 \\
(-0.03)\end{array}$ \\
\hline $2 a$ & $\begin{array}{l}-0.024 \\
(-1.44)\end{array}$ & $\begin{array}{l}5.323^{\mathrm{a}} \\
(3.17)\end{array}$ & $\begin{array}{l}3.041^{\mathrm{a}} \\
(3.75)\end{array}$ & $\begin{array}{c}20.116 \\
(0.14)\end{array}$ & - & - & - & - \\
\hline $2 b$ & $\begin{array}{l}0.010 \\
(0.49)\end{array}$ & $\begin{array}{l}1.028 \\
(0.63)\end{array}$ & $\begin{array}{l}2.926^{\mathrm{a}} \\
(2.79)\end{array}$ & $\begin{array}{l}105.42 \\
(-1.21)\end{array}$ & $\begin{array}{c}-0.060^{\mathrm{b}} \\
(-2.42)\end{array}$ & $\begin{array}{l}8.929^{\mathrm{a}} \\
(7.90)\end{array}$ & $\begin{array}{l}4.602^{\mathrm{a}} \\
(4.29)\end{array}$ & $\begin{array}{c}361.79^{\mathrm{a}} \\
(4.28)\end{array}$ \\
\hline $2 c$ & $\begin{array}{l}0.074 \\
(1.30)\end{array}$ & $\begin{array}{l}-5.672 \\
(-1.15)\end{array}$ & $\begin{array}{l}1.824 \\
(1.14)\end{array}$ & $\begin{array}{c}-168.02 \\
(-1.63)\end{array}$ & $\begin{array}{l}-0.119^{b} \\
(-2.01)\end{array}$ & $\begin{array}{l}6.201^{\mathrm{a}} \\
(4.35)\end{array}$ & $\begin{array}{l}3.696^{\mathrm{a}} \\
(6.75)\end{array}$ & $\begin{array}{l}239.37 \\
(1.53)\end{array}$ \\
\hline $3 a$ & $\begin{array}{l}-0.015 \\
(-1.19)\end{array}$ & $\begin{array}{l}5.390^{\mathrm{a}} \\
(3.25)\end{array}$ & $\begin{array}{l}3.131^{\mathrm{a}} \\
(4.20)\end{array}$ & $\begin{array}{l}-1.353 \\
(-1.47)\end{array}$ & - & - & - & - \\
\hline $3 b$ & $\begin{array}{l}0.013 \\
(0.72)\end{array}$ & $\begin{array}{l}0.641 \\
(0.40)\end{array}$ & $\begin{array}{l}3.102^{\mathrm{a}} \\
(3.15)\end{array}$ & $\begin{array}{l}-1.842^{\mathrm{a}} \\
(-2.94)\end{array}$ & $\begin{array}{l}-0.033 \\
(-1.53)\end{array}$ & $\begin{array}{l}9.100^{\mathrm{a}} \\
(7.30)\end{array}$ & $\begin{array}{l}5.139^{a} \\
(3.93)\end{array}$ & $\begin{array}{l}0.621 \\
(0.28)\end{array}$ \\
\hline $3 c$ & $\begin{array}{l}0.062 \\
(1.20)\end{array}$ & $\begin{array}{l}-5.983 \\
(-1.12)\end{array}$ & $\begin{array}{l}1.945 \\
(1.12)\end{array}$ & $\begin{array}{l}-0.665 \\
(-0.62)\end{array}$ & $\begin{array}{l}-0.086 \\
(-1.62)\end{array}$ & $\begin{array}{l}6.267^{\mathrm{a}} \\
(4.47)\end{array}$ & $\begin{array}{l}3.763^{\mathrm{a}} \\
(6.20)\end{array}$ & $\begin{array}{l}-0.237 \\
(-0.19)\end{array}$ \\
\hline $4 a$ & $\begin{array}{l}-0.028^{\mathrm{b}} \\
(-2.00)\end{array}$ & $\begin{array}{l}5.310^{\mathrm{a}} \\
(3.13)\end{array}$ & $\begin{array}{l}3.037^{a} \\
(3.67)\end{array}$ & $\begin{array}{c}76.119 \\
(0.68)\end{array}$ & - & - & - & - \\
\hline $4 b$ & $\begin{array}{l}0.003 \\
(0.15)\end{array}$ & $\begin{array}{l}0.734 \\
(0.41)\end{array}$ & $\begin{array}{l}2.909^{\mathrm{a}} \\
(2.65)\end{array}$ & $\begin{array}{l}-0.864 \\
(-0.01)\end{array}$ & $\begin{array}{l}-0.036 \\
(-1.62)\end{array}$ & $\begin{array}{l}9.020^{\mathrm{a}} \\
(7.58)\end{array}$ & $\begin{array}{l}4.823^{\mathrm{a}} \\
(4.47)\end{array}$ & $\begin{array}{c}175.00^{\mathrm{c}} \\
(1.95)\end{array}$ \\
\hline $4 c$ & $\begin{array}{l}0.062 \\
(1.06)\end{array}$ & $\begin{array}{l}-6.069 \\
(-1.13)\end{array}$ & $\begin{array}{l}1.786 \\
(1.02)\end{array}$ & $\begin{array}{c}-36.957 \\
(-0.30)\end{array}$ & $\begin{array}{l}-0.099 \\
(-1.66)\end{array}$ & $\begin{array}{l}6.287^{a} \\
(4.42)\end{array}$ & $\begin{array}{l}3.750^{\mathrm{a}} \\
(6.70)\end{array}$ & $\begin{array}{l}150.56 \\
(1.26)\end{array}$ \\
\hline $5 a$ & $\begin{array}{l}-0.006 \\
(-0.45)\end{array}$ & $\begin{array}{l}5.024^{\mathrm{a}} \\
(3.16)\end{array}$ & $\begin{array}{l}2.223^{\mathrm{a}} \\
(3.94)\end{array}$ & $\begin{array}{l}-1.731^{\mathrm{b}} \\
(-2.02)\end{array}$ & - & - & - & - \\
\hline $5 b$ & $\begin{array}{l}0.008 \\
(0.33)\end{array}$ & $\begin{array}{l}1.872 \\
(0.90)\end{array}$ & $\begin{array}{l}2.441^{b} \\
(2.56)\end{array}$ & $\begin{array}{l}-1.960^{\mathrm{C}} \\
(-1.97)\end{array}$ & $\begin{array}{l}-0.005 \\
(-0.19)\end{array}$ & $\begin{array}{l}7.731^{\mathrm{a}} \\
(5.35)\end{array}$ & $\begin{array}{l}2.873^{b} \\
(2.46)\end{array}$ & $\begin{array}{l}-0.802 \\
(-0.43)\end{array}$ \\
\hline $5 c$ & $\begin{array}{l}0.070 \\
(1.23)\end{array}$ & $\begin{array}{l}-5.601 \\
(-0.99)\end{array}$ & $\begin{array}{l}1.777 \\
(1.06)\end{array}$ & $\begin{array}{l}-1.316 \\
(-0.80)\end{array}$ & $\begin{array}{l}-0.082 \\
(-1.39)\end{array}$ & $\begin{array}{l}5.575^{\mathrm{a}} \\
(3.88)\end{array}$ & $\begin{array}{l}2.272^{\mathrm{a}} \\
(4.44)\end{array}$ & $\begin{array}{l}-1.246 \\
(-1.02)\end{array}$ \\
\hline $6 a$ & $\begin{array}{l}-0.024 \\
(-1.47)\end{array}$ & $\begin{array}{l}4.883^{a} \\
(3.02)\end{array}$ & $\begin{array}{l}2.215^{\mathrm{a}} \\
(3.49)\end{array}$ & $\begin{array}{c}98.074 \\
(0.72)\end{array}$ & - & - & - & - \\
\hline $6 b$ & $\begin{array}{l}-0.004 \\
(-0.15)\end{array}$ & $\begin{array}{l}2.018 \\
(1.02)\end{array}$ & $\begin{array}{l}2.435^{\mathrm{b}} \\
(2.23)\end{array}$ & $\begin{array}{l}-4.873 \\
(-0.04)\end{array}$ & $\begin{array}{l}-0.036 \\
(-1.07)\end{array}$ & $\begin{array}{l}7.630^{\mathrm{a}} \\
(5.70)\end{array}$ & $\begin{array}{l}2.470^{\mathrm{b}} \\
(2.57)\end{array}$ & $\begin{array}{c}409.77^{\mathrm{a}} \\
(4.11)\end{array}$ \\
\hline $6 c$ & $\begin{array}{l}0.078 \\
(1.38)\end{array}$ & $\begin{array}{l}-5.630 \\
(-1.06)\end{array}$ & $\begin{array}{l}1.523 \\
(0.94)\end{array}$ & $\begin{array}{c}-158.26 \\
(-1.35)\end{array}$ & $\begin{array}{l}-0.125^{b} \\
(-2.16)\end{array}$ & $\begin{array}{l}5.517^{\mathrm{a}} \\
(3.95)\end{array}$ & $\begin{array}{l}2.407^{\mathrm{a}} \\
(4.62)\end{array}$ & $\begin{array}{c}351.82^{\mathrm{a}} \\
(3.20)\end{array}$ \\
\hline $7 a$ & $\begin{array}{l}-0.016 \\
(-0.94)\end{array}$ & $\begin{array}{l}4.962^{a} \\
(3.06)\end{array}$ & $\begin{array}{l}2.198^{\mathrm{a}} \\
(3.60)\end{array}$ & $\begin{array}{l}0.038 \\
(0.03)\end{array}$ & - & - & - & - \\
\hline $7 b$ & $\begin{array}{l}0.005 \\
(0.16)\end{array}$ & $\begin{array}{l}1.754 \\
(0.76)\end{array}$ & $\begin{array}{l}2.493^{b} \\
(2.63)\end{array}$ & $\begin{array}{l}-1.150 \\
(-0.97)\end{array}$ & $\begin{array}{l}-0.015 \\
(-0.46)\end{array}$ & $\begin{array}{l}7.770^{\mathrm{a}} \\
(5.59)\end{array}$ & $\begin{array}{l}3.281^{\mathrm{a}} \\
(3.06)\end{array}$ & $\begin{array}{l}1.722 \\
(1.43)\end{array}$ \\
\hline $7 c$ & $\begin{array}{l}0.066 \\
(1.16)\end{array}$ & $\begin{array}{l}-5.806 \\
(-1.04)\end{array}$ & $\begin{array}{l}1.627 \\
(0.97)\end{array}$ & $\begin{array}{l}-0.601 \\
(-0.39)\end{array}$ & $\begin{array}{l}-0.090 \\
(-1.53)\end{array}$ & $\begin{array}{l}5.699^{\mathrm{a}} \\
(4.14)\end{array}$ & $\begin{array}{l}2.388^{\mathrm{a}} \\
(4.94)\end{array}$ & $\begin{array}{l}0.869 \\
(0.61)\end{array}$ \\
\hline $8 a$ & $\begin{array}{l}-0.034^{\mathrm{c}} \\
(-1.90)\end{array}$ & $\begin{array}{l}4.993^{\mathrm{a}} \\
(3.30)\end{array}$ & $\begin{array}{l}2.421^{\mathrm{a}} \\
(3.43)\end{array}$ & $\begin{array}{c}139.51 \\
(1.55)\end{array}$ & - & - & - & - \\
\hline $8 b$ & $\begin{array}{l}-0.004 \\
(-0.14)\end{array}$ & $\begin{array}{l}2.010 \\
(0.99)\end{array}$ & $\begin{array}{l}2.435^{b} \\
(2.14)\end{array}$ & $\begin{array}{l}-2.342 \\
(-0.02)\end{array}$ & $\begin{array}{l}-0.028 \\
(-0.79)\end{array}$ & $\begin{array}{l}7.609^{\mathrm{a}} \\
(6.05)\end{array}$ & $\begin{array}{l}3.029^{\mathrm{a}} \\
(3.07)\end{array}$ & $\begin{array}{c}200.90^{\mathrm{a}} \\
(4.17)\end{array}$ \\
\hline $8 c$ & $\begin{array}{l}0.079 \\
(1.35)\end{array}$ & $\begin{array}{l}-5.759 \\
(-1.09)\end{array}$ & $\begin{array}{l}1.484 \\
(0.90)\end{array}$ & $\begin{array}{c}-124.32 \\
(-1.21)\end{array}$ & $\begin{array}{l}-0.132^{\mathrm{b}} \\
(-2.19)\end{array}$ & $\begin{array}{l}5.793^{\mathrm{a}} \\
(4.97)\end{array}$ & $\begin{array}{l}2.860^{\mathrm{a}} \\
(6.05)\end{array}$ & $\begin{array}{c}267.49^{\mathrm{a}} \\
(4.25)\end{array}$ \\
\hline
\end{tabular}

Notes: See Table 6. 
To conclude, when splitting the sample before and after the start of EMU, volatility is not significant in most cases, and no clear pattern emerges before and after that date. The exception was Italy, where the coefficient on volatility (both nominal and real) is positive and significant before the adoption of the euro, losing its significance afterwards.

Finally, notice that in this paper we have followed the most common approach to assess the effect of exchange rate volatility on exports, that is, estimating a standard (i.e., linear) exports function, augmented to include the role of volatility. However, it might be possible that the effect of volatility on exports were nonlinear instead. For instance, recall that the EGARCH model (Nelson, 1991) used as a proxy of exchange rate volatility, is based on the assumption that volatility is asymmetrical, i.e., responds differently, in this case, to an appreciation or to a depreciation of the exchange rate. Thus, we might generalise this behaviour, with exports responding asymmetrically to changes in volatility (i.e., positive or negative). Also, another possibility would be performing a threshold cointegration analysis following the approach of Hansen and Seo (2002); recall that we found no evidence of cointegration even allowing for a break. In that case, a cointegrating relationship will appear only if the system gets 'too far' from the equilibrium; i.e., cointegration holds only if the system exceeds a certain threshold. While it is not too clear theoretically what the threshold would be, all the above are no doubt interesting extensions that can be taken into consideration for further work.

\section{Conclusions}

The current economic crisis has witnessed a strong deceleration in the growth of international trade, which has been even greater in the cases of the EU and the eurozone. In this paper, we have explored to which extent exchange rate volatility might be behind the fall in the rate of growth of exports in the eurozone since the start of the crisis. Accordingly, we have estimated export functions, augmented to include several measures of exchange rate volatility, for the four largest economies of the eurozone, i.e., France, Germany, Italy and Spain, for the period 1994:1-2014:4. In the empirical application, we have examined the role of the volatility of both nominal and real exchange rates; and, in the latter case, two real exchange rates have been used, computed using as deflators export prices and unit labour costs. In addition, exchange rate volatility has been measured in two alternative ways: (i) as the standard deviation of the change in the logarithm of the exchange rate; and (ii) as the conditional variance of the change in the logarithm of the exchange rate from the estimation of an EGARCH model.

The empirical results show no clear-cut evidence on the impact of exchange rate volatility on the exports of the countries analysed. For the whole sample, the effect was generally not significant, with the exception of the negative and significant role found for nominal exchange rate volatility in the case of Germany. Next, we split the sample before and after the start of the crisis, by introducing a dummy variable equal to one from 2008:4 on. The results for the first subperiod were roughly the same than those for the whole period, but some differences appeared for the second subperiod, especially when volatility was measured as the conditional variance from an EGARCH model. Now, a positive and significant effect was found in the crisis period for nominal volatility for France, Italy and Spain; unlike Germany, where the effect was 
negatively signed (even though significant just at the $10 \%$ level). In turn, in the case of real volatility, a positive and significant effect was found for the four countries (just for the REER computed using export prices in the case of Italy). Interestingly, the effect of foreign output on exports seemed to be stronger during the crisis period. Finally, when splitting the sample before and after the start of EMU, volatility was not significant in most cases, with no clear pattern emerging. Only for Italy a positive and significant effect of volatility (both nominal and real) was found before the adoption of the euro, which seemed to disappear afterwards. Overall, these results suggest that financial markets are developed enough, at least in advanced countries, so that exchange rate volatility has not hindered the evolution of exports. In addition, when coupled with the results in Bajo-Rubio et al. (2016), boosting world demand appears as the main factor that might encourage a recovery of European trade throughout the current crisis.

Acknowledgements The authors wish to acknowledge the comments of María A. Prats and three anonymous referees, as well as the econometric advice of Jorge V. Pérez-Rodríguez. Financial support from the Spanish Ministry of Economy, Industry and Competitiveness, through the project ECO201678422-R, and the University of Castilla-La Mancha, through the project 2019-GRIN-26952 (O. BajoRubio), is also gratefully acknowledged. 


\section{References}

Aristotelous, K. (2001): Exchange-rate volatility, exchange-rate regime, and trade volume: Evidence from the UK-US export function (1889-1999). Economics Letters 72(1): 87-94.

https://econpapers.repec.org/article/eeeecolet/v_3a72_3ay_3a2001_3ai_3a1_3ap_3a87-94.htm

Arize, A.C. (1997): Conditional exchange-rate volatility and the volume of foreign trade: Evidence from seven industrialized countries. Southern Economic Journal 64(1): 235-254.

https://www.jstor.org/stable/1061049?seq=1

Arize, A.C., Osang, T., and Slottje, D. J. (2000): Exchange-rate volatility and foreign trade: Evidence from thirteen LDC's, Journal of Business \& Economic Statistics 18(1): 10-17.

https://econpapers.repec.org/article/besjnlbes/v_3a18_3ay_3a2000_3ai_3a1_3ap_3a10-17.htm

Bahmani-Oskooee, M., and Hegerty, S.W. (2007): Exchange rate volatility and trade flows: A review article. Journal of Economic Studies 34(3): 211-255.

https://econpapers.repec.org/article/emejespps/v_3a34_3ay_3a2007_3ai_3a3_3ap_3a211-255.htm

Bajo-Rubio, O., Berke, B., and Esteve, V. (2016): The effects of competitiveness on trade balance: The case of Southern Europe. Economics: The Open-Access, Open-Assessment E-Journal, 10 (2016-30):1-26. http://dx.doi.org/10.5018/economics-ejournal.ja.2016-30

Barkoulas, J.T., Baum, C.F., and Çağlayan, M. (2002): Exchange rate effects on the volume and variability of trade flows. Journal of International Money and Finance 21(4): 481-496. https://econpapers.repec.org/article/eeejimfin/v_3a21_3ay_3a2002_3ai_3a4_3ap_3a481-496.htm

Bollerslev, T. (1986): Generalized autoregressive conditional heteroscedasticity. Journal of Econometrics 31(3): 307-327.

https://econpapers.repec.org/article/eeeeconom/v_3a31_3ay_3a1986_3ai_3a3_3ap_3a307-327.htm

Bouoiyour, J., and Selmi, R. (2016): A synthesis of the effects of exchange rate volatility on international trade: A meta-regression analysis. The International Trade Journal 30(4): 263-294.

https://econpapers.repec.org/article/tafuitjxx/v_3a30_3ay_3a2016_3ai_3a4_3ap_3a263-294.htm

Broll, U., and Eckwert, B. (1999): Exchange rate volatility and international trade. Southern Economic Journal 66(1): 178-185. https://www.jstor.org/stable/1060843

Chowdhury, A.R. (1993): Does exchange rate volatility depress trade flows? Evidence from errorcorrection models. Review of Economics and Statistics 75(4): 700-706.

https://econpapers.repec.org/article/tprrestat/v_3a75_3ay_3a1993_3ai_3a4_3ap_3a700-706.htm

Ćorić, B., and Pugh, G. (2010): The effects of exchange rate variability on international trade: A metaregression analysis. Applied Economics 42(20): 2631-2644.

https://econpapers.repec.org/article/tafapplec/v_3a42_3ay_3a2010_3ai_3a20_3ap_3a2631-

2644.htm

Côté, A. (1994): Exchange rate volatility and trade: A survey. Working Paper 94-5, Bank of Canada, Ottawa. https://www.bankofcanada.ca/1994/05/working-paper-1994-5/

De Grauwe, P. (1988): Exchange rate variability and the slowdown in growth of international trade. IMF Staff Papers 35(1): 63-84.

https://econpapers.repec.org/article/palimfstp/v_3a35_3ay_3a1988_3ai_3a1_3ap_3a63-84.htm 
Dellas, H., and Zilberfarb, B.-Z. (1993): Real exchange rate volatility and international trade: A reexamination of the theory. Southern Economic Journal 59(4): 641-647. https://www.jstor.org/stable/1059729?seq=1

Dornbusch, R. (1976): Expectations and exchange rate dynamics. Journal of Political Economy 84(6): 1161-1176. https://econpapers.repec.org/article/ucpjpolec/v_3a84_3ay_3a1976_3ai_3a6_3ap_3a1161-76.htm

Doroodian, K. (1999): Does exchange rate volatility deter international trade in developing countries? Journal of Asian Economics 10(3): 465-474. https://econpapers.repec.org/article/eeeasieco/v_3a10_3ay_3a1999_3ai_3a3_3ap_3a465-474.htm

Engle, R.F. (1982): Autoregressive conditional heteroskedasticity with estimates of the variance of U.K. inflation. Econometrica 50(4): 987-1008. https://econpapers.repec.org/article/eeeasieco/v_3a10_3ay_3a1999_3ai_3a3_3ap_3a465-474.htm

Ethier, W. (1973): International trade and the forward exchange market. American Economic Review 63 (63): 494-503. https://econpapers.repec.org/article/aeaaecrev/v_3a63_3ay_3a1973_3ai_3a3_3ap_3a494-503.htm

Franke, G. (1991): Exchange rate volatility and international trading strategy. Journal of International Money and Finance 10(2): 292-307. https://econpapers.repec.org/article/eeejimfin/v_3a10_3ay_3a1991_3ai_3a2_3ap_3a292-307.htm

Goldstein, M., and Khan, M.S. (1985): Income and price effects in foreign trade. In R.W. Jones and P.B. Kenen (eds.): Handbook of International Economics, vol. 2, North-Holland, Amsterdam, 10411105. http://econpapers.repec.org/bookchap/eeeintchp/2-20.htm

Gotur, P. (1985): Effects of exchange rate volatility on trade: Some further evidence. IMF Staff Papers 32(3): 475-512. https://econpapers.repec.org/article/palimfstp/v_3a32_3ay_3a1985_3ai_3a3_3ap_3a475-512.htm

Gregory, A.W. and Hansen, B.E. (1996): Residual-based tests for cointegration in models with regime shifts. Journal of Econometrics 70(1): 99-126. https://econpapers.repec.org/article/eeeeconom/v_3a70_3ay_3a1996_3ai_3a1_3ap_3a99-126.htm

Grier, K.B., and Smallwood, A.D. (2007): Uncertainty and export performance: Evidence from 18 countries. Journal of Money, Credit and Banking 39(4): 965-979. https://econpapers.repec.org/article/mcbjmoncb/v_3a39_3ay_3a2007_3ai_3a4_3ap_3a965979.htm

Group of Ten (1985): The Functioning of the International Monetary System. Report of the Deputies of the Group of Ten, June.

https://www.elibrary.imf.org/doc/IMF084/06523-9780939934768/065239780939934768/Other_formats/Source_PDF/06523-9781452717715.pdf

Hansen, B.E., and Seo, B. (2002): Testing for two-regime threshold cointegration in vector errorcorrection models. Journal of Econometrics 110(2): 293-318.

https://econpapers.repec.org/article/eeeeconom/v_3a110_3ay_3a2002_3ai_3a2_3ap_3a293318.htm 
Héricourt, J., and Poncet, S. (2015): Exchange rate volatility, financial constraints, and trade: Empirical evidence from Chinese firms. World Bank Economic Review 29(3): 550-578. https://econpapers.repec.org/article/oupwbecrv/v_3a29_3ay_3a2015_3ai_3a3_3ap_3a550578..htm

Hoekman, B. (2015): The Global Trade Slowdown: A New Normal? A VoxEU.org eBook, Centre for Economic Policy Research, London. https://voxeu.org/sites/default/files/file/Global\%20Trade\%20Slowdown_nocover.pdf

Hooper, P. and Kohlhagen, S.W. (1978): The effect of exchange rate uncertainty on the prices and volume of international trade. Journal of International Economics 8(4): 483-511. https://econpapers.repec.org/article/eeeinecon/v_3a8_3ay_3a1978_3ai_3a4_3ap_3a483-511.htm

Johansen, S. (1991): Estimation and hypothesis testing of cointegration vectors in Gaussian vector autoregressive models. Econometrica 59(6): 1551-1580. https://econpapers.repec.org/article/ecmemetrp/v_3a59_3ay_3a1991_3ai_3a6_3ap_3a1551-80.htm

Kenen, P.B. and Rodrik, D. (1986): Measuring and analysing the effects of short term volatility in real exchange rates. Review of Economics and Statistics 68(2): 311-315. https://econpapers.repec.org/article/tprrestat/v_3a68_3ay_3a1986_3ai_3a2_3ap_3a311-15.htm

Koray, F., and Lastrapes, W.D. (1989): Real exchange rate volatility and U.S. bilateral trade: A VAR approach. Review of Economics and Statistics 71(4): 708-712. https://econpapers.repec.org/article/tprrestat/v_3a71_3ay_3a1989_3ai_3a4_3ap_3a708-12.htm

MacKinnon, J.G., Haug, A.A., and Michelis, L. (1999): Numerical distribution functions of likelihood ratio tests for cointegration. Journal of Applied Econometrics 14(5): 563-577. https://econpapers.repec.org/article/jaejapmet/v_3a14_3ay_3a1999_3ai_3a5_3ap_3a563-77.htm

McKenzie, M.D. (1998): The impact of exchange rate volatility on Australian trade flows. Journal of International Financial Markets, Institutions and Money 8(1): 21-38. https://econpapers.repec.org/article/eeeintfin/v_3a8_3ay_3a1998_3ai_3a1_3ap_3a21-38.htm

McKenzie, M.D. (1999): The impact of exchange rate volatility on international trade flows. Journal of Economic Surveys 13(1): 71-106. https://econpapers.repec.org/article/blajecsur/v_3a13_3ay_3a1999_3ai_3a1_3ap_3a71-106.htm

McKenzie, M.D., and Brooks, R.D. (1997): The impact of exchange rate volatility on German-US trade flows. Journal of International Financial Markets, Institutions and Money 7(1): 73-87. https://econpapers.repec.org/article/eeeintfin/v_3a7_3ay_3a1997_3ai_3a1_3ap_3a73-87.htm

Mordecki, G., and Miranda, R. (2019): Real exchange rate volatility and exports: A study for four selected commodity exporting countries. Panoeconomicus 66(4): 411-437. http://panoeconomicus.org/index.php/jorunal/article/view/412

Mussa, M. (1979): Empirical regularities in the behavior of exchange rates and theories of the foreign exchange market. Carnegie-Rochester Conference Series on Public Policy 11(1): 9-57. https://econpapers.repec.org/article/eeecrcspp/v_3a11_3ay_3a1979_3ai_3a_3ap_3a9-57.htm

Nelson, D.B. (1991): Conditional heteroskedasticity in asset returns: A new approach. Econometrica 59(2): 347-370.

https://econpapers.repec.org/article/ecmemetrp/v_3a59_3ay_3a1991_3ai_3a2_3ap_3a347-70.htm 
Newey, W.K., and West, K.D. (1987): A simple positive semi-definite, heteroskedasticity and autocorrelation consistent covariance matrix. Econometrica 55(3): 703-708.

https://econpapers.repec.org/article/ecmemetrp/v_3a55_3ay_3a1987_3ai_3a3_3ap_3a703-08.htm

Ng, S., and Perron, P. (2001): Lag length selection and the construction of unit root tests with good size and power. Econometrica 69(6): 1519-1554.

https://econpapers.repec.org/article/ecmemetrp/v_3a69_3ay_3a2001_3ai_3a6_3ap_3a15191554.htm

Obstfeld, M. (1985): Floating exchange rates: Experience and prospects. Brookings Papers on Economic Activity 16(2): 369-464.

https://econpapers.repec.org/article/binbpeajo/v_3a16_3ay_3a1985_3ai_3a1985-2_3ap_3a369464.htm

Perée, E., and Steinherr, A. (1989): Exchange rate uncertainty and foreign trade. European Economic Review 33(6): 1241-1264.

https://econpapers.repec.org/article/eeeeecrev/v_3a33_3ay_3a1989_3ai_3a6_3ap_3a1241-

1264.htm

Perron, P. (1989): The Great Crash, the oil price shock, and the unit root hypothesis. Econometrica 57(6): 1361-1401.

https://econpapers.repec.org/article/ecmemetrp/v_3a57_3ay_3a1989_3ai_3a6_3ap_3a1361-

1401.htm

Pozo, S. (1992): Conditional exchange-rate volatility and the volume of international trade: Evidence from the early 1900s. Review of Economics and Statistics 74(2): 325-329.

https://econpapers.repec.org/article/tprrestat/v_3a74_3ay_3a1992_3ai_3a2_3ap_3a325-29.htm

Sercu, P. (1992): Exchange risk, exposure, and the option to trade. Journal of International Money and Finance 11(6): 579-593.

https://econpapers.repec.org/article/eeejimfin/v_3a11_3ay_3a1992_3ai_3a6_3ap_3a579-593.htm

Tenreyro, S. (2007): On the trade impact of nominal exchange rate volatility. Journal of Development Economics 82(2): 485-508.

https://econpapers.repec.org/article/eeedeveco/v_3a82_3ay_3a2007_3ai_3a2_3ap_3a485-508.htm

Thursby, J.G., and Thursby, M. C. (1987): Bilateral trade flows, the Linder hypothesis, and exchange risk. Review of Economics and Statistics 69(3): 488-495.

https://econpapers.repec.org/article/tprrestat/v_3a69_3ay_3a1987_3ai_3a3_3ap_3a488-95.htm

Vogelsang, T. J. (1993): Unpublished computer program.

Williamson, J. (1983): The exchange rate system. Institute for International Economics, Washington, DC. 